\title{
An Integrated Stratigraphy of the Frasnian-Famennian Boundary Interval (Late Devonian) in the Moravian Karst (Czech Republic) and Kellerwald (Germany)
}

\author{
TOMÁŠ WEINER, JIŘí KALVODA, TOMÁŠ KUMPAN, EBERHARD SCHINDLER \& DANIEL ŠIMÍČEK
}

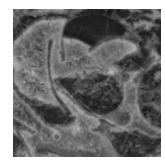

\begin{abstract}
Rapid and profound changes in Earth surface environments and biota across the Frasnian-Famennian (Fr-Fa) boundary are well known and related to one of the five most severe mass extinction events in Earth history. Here, we present sedimentological, biostratigraphical, petrophysical (gamma-ray spectrometry, magnetic susceptibility) and geochemical (X-ray fluorescence) data from environmentally distinct sections in the Moravian Karst (Czech Republic) and compare them with the Steinbruch Schmidt section in the Kellerwald (Rheinisches Schiefergebirge, Germany). Both areas were located at the southern margin of Laurussia. The studied sections span the interval from the Lower or Upper rhenana to the Palmatolepis minuta minuta or younger conodont zones and the foraminiferal Eonodosaria evlanensis Zone and Eonodosaria evlanensis-Quasiendothyra communis Interzone including high resolution biozonation of the Fr-Fa boundary interval. In the Moravian Karst pure limestone facies of an inclined carbonate ramp reflect the worldwide trend in the widespread occurrence of calcimicrobes during upper Frasnian and lower Famennian. Geochemical and petrophysical data show a decrease in grain size of the siliciclastic supply and carbonate productivity in the Kellwasser Event intervals probably due to a deepening and correlate with maximum flooding surfaces and highstand system tracts in the Steinbruch Schmidt. Certain differences in some geochemical proxies between the Moravian Karst and Steinbruch Schmidt are due to lower carbonate dilution of the latter. Significant $\mathrm{Zr}, \mathrm{TiO}_{2}, \mathrm{Mn}_{\mathrm{or} \mathrm{Fe}} \mathrm{O}_{3}$ enrichments may indicate the influence of volcanic sources in the studied Moravian Karst Fr-Fa sections. - Key words: Frasnian-Famennian boundary, Kellwasser Events, conodont and foraminifer biostratigraphy, microfacies, gamma-ray spectrometry, magnetic susceptibility, element geochemistry.
\end{abstract}

Weiner, T., Kalvoda, J., Kumpan, T., Schindler, E. \& ŠimíčEK, D. 2017. An Integrated Stratigraphy of the Frasnian-Famennian Boundary Interval (Late Devonian) in the Moravian Karst (Czech Republic) and Kellerwald (Germany). Bulletin of Geosciences 92(2), 257-281 (9 figures, 3 tables, electronic supplementary appendix). Czech Geological Survey, Prague. ISSN 1214-1119. Manuscript received September 19, 2016; accepted in revised form June 13, 2017; published online June 30, 2017; issued June 30, 2017.

Tomáš Weiner, Jiři Kalvoda \& Tomáš Kumpan, Department of Geological Sciences, Masaryk University, Kotlářská 2, 61137 Brno,Czech Republic; tomasweiner@seznam.cz,dino@sci.muni.cz,kumpan.tom@gmail.com・Eberhard Schindler, Senckenberg Forschungsinstitut und Naturmuseum Frankfurt, Senckenberganlage 25, 60325 Frankfurt am Main, Germany; Eberhard.Schindler@senckenberg.de •Daniel Šimíček, Department of Geology, Palacký University, 17. listopadu 12, 77200 Olomouc, Czech Republic; daniel.simicek@upol.cz.

The end-Frasnian Kellwasser Events (KWE) and the Frasnian-Famennian (Fr-Fa) boundary are well known for their linkage with one of the five most intensive mass extinctions of the Phanerozoic (McLaren 1970, Hallam \& Wignall 1997, House 2002, Racki 2005, McGhee 2013). The series of extinctions collectively comprise the Kellwasser Crisis which represents rather long time interval (1 my in total) including the Lower and Upper Kellwasser Events (LKE and UKE) (Gereke \& Schindler 2012). According to the standard conodont zonation (sensu Ziegler \& Sandberg 1990), the LKE is assigned to the lower part of the Upper rhenana Zone, whereas the UKE represents the upper part of the linguiformis Zone (Ziegler \& Sandberg 1990, Schindler 1990b, Feist \& Schindler 1994).

The Givetian-Frasnian coral-stromatoporoid reef ecosystems were significantly affected right from the beginning of the Kellwasser Crisis slightly prior to the onset of the LKE (McGhee 1996, Kiessling et al. 2000, Copper 2002) and various groups, such as trilobites, cephalopods, tentaculitoids, conodonts, brachiopods and some terrestrial biota suffered significant losses before the end of the UKE 
in the uppermost Frasnian (Schindler 1990a, b; McGhee 1996; Walliser 1996; Gereke 2007; McGhee 2013; Huang \& Gong 2016). Among others, these authors discussed various causes of the extinctions, including climatic oscillations (Joachimski \& Buggisch 2002, Joachimski et al. 2002) connected with astronomical forcing (De Vleeschouwer et al. 2014), volcanic, tectonic and hydrothermal activity (Algeo et al. 1995; Murphy et al. 2000; Joachimski et al. 2001; Racki et al. 2002; Pujol et al. 2006; Riquier et al. 2005, 2006; Bond et al. 2013; George et al. 2014), and impacts of extraterrestrial bodies ( $c f$. McLaren 1970; Racki 2005, 2012). A multicausal scenario of earthbound mechanisms is currently accepted rather than the cosmic disasters ( $c f$. Racki 2005; Schindler 1990a, b; see also House 2002; McGhee 2013). The Kellwasser Events are thought to be connected with prevailing hypoxic conditions, which are supposed to be the result of eutrophication triggered by an increased input of nutrients (Algeo et al. 1995; Murphy et al. 2000; Joachimski et al. 2001; Racki et al. 2002; Pujol et al. 2006; Riquier et al. 2005, 2006; Bond et al. 2013; George et al. 2014; Rakociński et al. 2016).

The LKE and UKE (see Walliser 1996) were recorded in various sections over the globe (Feist 1985, Schindler 1990b, Wendt \& Belka 1991, Lazreq 1999, Over 2002, Yudina et al. 2002, Chen et al. 2005, George et al. 2014, Dopieralska et al. 2016). In some sections, however, the Fr-Fa boundary is coupled with hiatuses, unconformities and distinctive facies changes (e.g. Bratton et al. 1999, Alekseev et al. 1996, Chen \& Tucker 2004, Bond \& Wignall 2008, Zatoń et al. 2014).

Riquier et al. (2006) proposed different causes of anoxia in both Kellwasser Events. The LKE anoxia were interpreted as the result of increased primary productivity, enhanced by land-derived nutrient loading, whereas the UKE was conceived as the result of the onset of oxygen-impoverished bottom water in the deepest part of the ocean, due to episodic water stratification during the maximum Frasnian transgression. However, the effect of increased land-plant growth combined with stronger weathering (soils) and nutrient influx was considered as significant for the entire Kellwasser Crisis (Algeo et al. 1995, Algeo \& Scheckler 1998).

Multi-proxy stratigraphic analysis based on petrophysical gamma-ray spectrometry (GRS) and magnetic susceptibility (MS) properties of sedimentary successions proved a useful approach to stratigraphic correlation and palaeoenvironmental analysis of key stratigraphic intervals during the Palaeozoic. The main benefits of the GRS and MS techniques are the rapid and inexpensive acquisition of large quantitative datasets and the well-studied causal relationships between measured parameters and sedimentary processes, such as detrital input into carbonate platforms, redox conditions at the sediment-water interface and diagenetic history (e.g. Ellwood et al. 2000; Ruffell \& Worden 2000; Lüning et al. 2003; Halgedahl et al. 2009; da Silva et al. 2009, 2013; Bábek et al. 2010, 2013; Koptíková et al. 2010; Whalen \& Day 2010). When combined with element geochemistry data, the interpretative power of GRS and/or MS for genetic stratigraphy greatly increases, as was demonstrated in several recent papers addressing the Devonian-Carboniferous boundary (Kumpan et al. 2014a, b; 2015; Bábek et al. 2016) and the GivetianFrasnian boundary (Devleeschouwer et al. 2015). The petrophysical record of the Fr-Fa boundary was discussed in several papers mostly providing data either on MS (e.g. Crick et al. 2002, Hladil et al. 2006, Whalen \& Day 2010), GRS (Hladil 2002, Bond \& Zatoń 2003, Hladil et al. 2006, Bábek et al. 2007, Bond et al. 2013) or on stable isotopes and elemental geochemistry (e.g. Joachimski \& Buggisch 1993, Yudina et al. 2002, Riquier et al. 2005, George et al. 2014). Multi-proxy data combining the petrophysical and geochemical signature of this interval are, however, rare (Racki et al. 2002, Bond et al. 2004, Whalen et al. 2015).

In this paper, we provide new data on the Fr-Fa interval in three previously unpublished sections (Fig. 1) in the Moravian Karst (Moravo-Silesian Zone of the Bohemian Massif, Czech Republic) including conodont and foraminifer biostratigraphy, microfacies analysis, field GRS, MS and bulk-rock element geochemistry. They are correlated with the Steinbruch Schmidt section (Kellerwald, Germany) which was studied in the same way using petrophysical and geochemical tools. This section exposes lithologically distinctive KWE horizons and represents the former auxiliary stratotype which is - compared to the stratotype Coumiac section - much thicker. The aim of our integrated stratigraphic study is to test correlative potential of the KWE sections without distinctive lithological changes and with less accurate resolution in biostratigraphic time control.

\section{Geological settings}

The Moravian sections are representative of a vast carbonate platform extending from eastern Moravia to southeastern Poland (Racki et al. 2002, Bábek et al. 2007). Moravia, Poland and the Kellerwald area were located in an epicontinental basin at the Rhenohercynian margin of Laurussia (Franke 1995, 2002; Kalvoda et al. 2008). The succession in Steinbruch Schmidt was deposited on a submarine rise (Fig. 1), below the wave-base level, and consists of condensed pelagic cephalopod limestones consisting of dark-grey to black limestones, marls and shales of the Kellwasser intervals (Buggisch 1972; Schindler 1990a, b; 1993). The late Frasnian-early Famennian sedimentary successions exposed at Hády (GPS 49 $\left.13^{\prime} 8^{\prime \prime} \mathrm{N} ; 16^{\circ} 40^{\prime} 20.7^{\prime \prime} \mathrm{E}\right)$, 

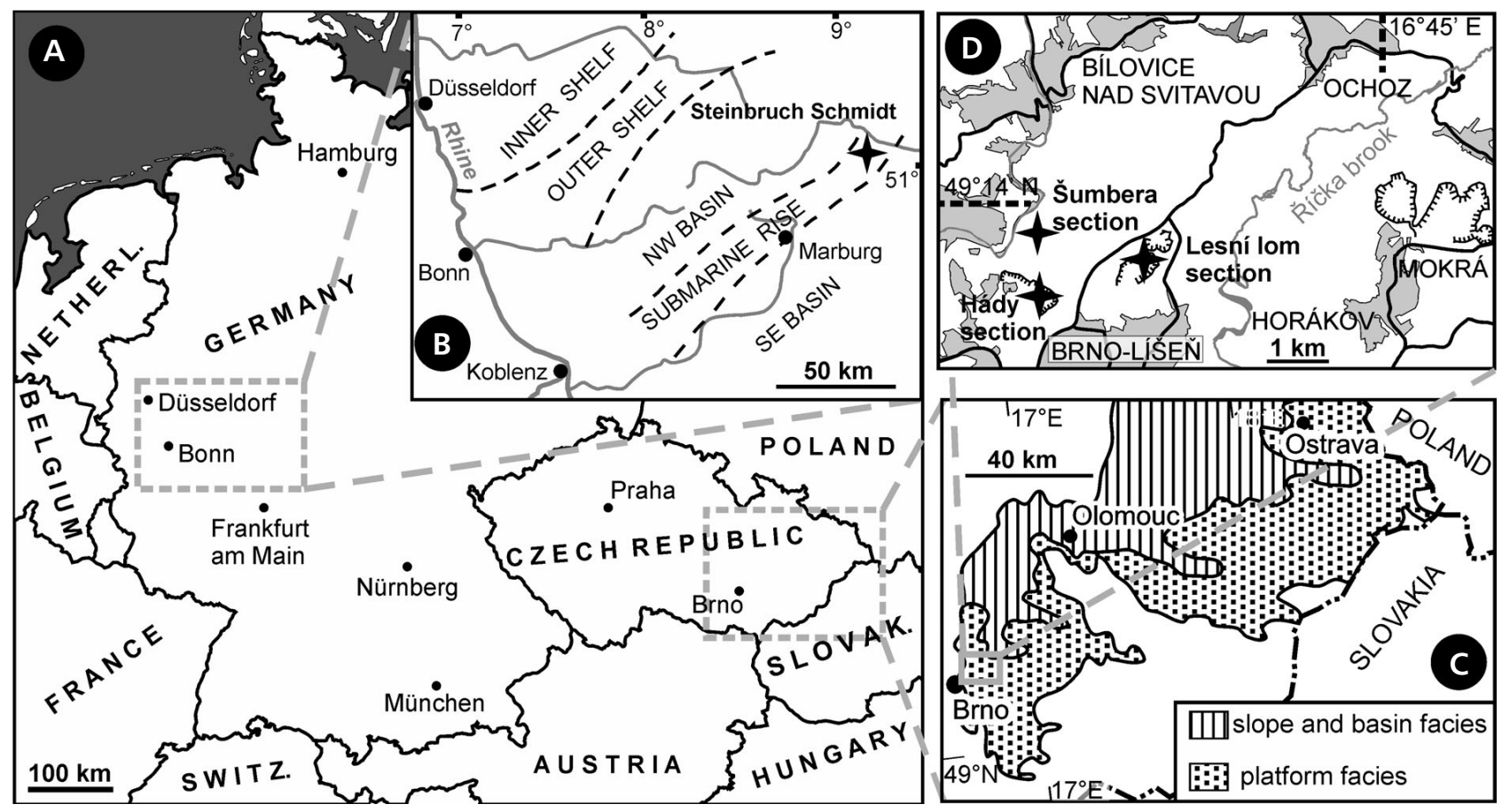

Figure 1. A - localization of studied areas in Central Europe. $\bullet \mathrm{B}$ - Late Devonian palaeogeographic and palaeoenvironmental scheme of the western Rheinisches Schiefergebirge with location of Steinbruch Schmidt. After Meischner (1971). C - schematic map of outcrop and subsurface facies of the Upper Devonian Carbonate platform of the Moravosilesian Basin. Modified after Bábek et al. (2007). • D - location of investigated sections in the southern part of the Moravian Karst.

Šumbera (49 $\left.13^{\prime} 37.7^{\prime \prime} \mathrm{N} ; 16^{\circ} 40^{\prime} 23.9^{\prime \prime} \mathrm{E}\right)$ and Lesní lom sections (GPS 49 $\left.13^{\prime} 28.89^{\prime \prime} \mathrm{N} ; 16^{\circ} 41^{\prime} 44.79^{\prime \prime} \mathrm{E}\right)$ are located on the outskirts of Brno. These sections comprise relatively pure limestones deposited on a carbonate ramp (Hladil et al. 1991), which, during the Famennian, progressively developed into a NW-SE-oriented halfgraben with the deposition of hemipelagic nodular limestones and carbonate turbidites (Kalvoda 1998, Kalvoda et al. 2008). Coeval interval was studied in the Moravian Karst in two localities. The Lesní lom section, investigated by Hladil et al. (1991), was quarried out and Šumbera sections studied by the previous authors (Hladil \& Kalvoda 1993a, Streitová 1994, Racki et al. 2002) were covered and as there were no coordinates given it was not possible to indentify them with the section presented in this paper.

\section{Materials and methods}

The profiles were logged in a bed-by-bed manner for microfacies characteristics. A total of 75 samples for microfacies analysis were taken at random intervals (see Figs 3-5). Polished sections and standard-sized thin-sections $(27 \times 46 \mathrm{~mm})$ were prepared. Thin-sections were studied using a polarising microscope Nikon Eclipse 80i connected to a Nikon DS-F1 digital camera. A total of 47 conodont samples (weight between $1-4 \mathrm{~kg}$ ) were analysed. The sam- ples were macerated in $15 \%$ solution of acetic acid. Insoluble residues were separated after the dissolution process using a $0.125 \mathrm{~mm}$ mesh size. Standard conodont zones based on Ziegler (1962, 1969), Ziegler \& Sandberg (1990) and revised Famennian conodont zones of Spalletta et al. (2017) are used in this paper. For further reading, we refer to Fig. 2 for correlation of the three previously published conodont zonations in the lower Famennian. In consistence with many other researches, we cite the zones of Ziegler \& Sandberg (1990) as Lower, Middle, Upper and Uppermost instead of Early, Middle, Late and Latest (see Spalletta et al. 2017).

A total of 191 field GRS assays were measured at the logged sections at 10 to $25 \mathrm{~cm}$ thick intervals, depending on section thickness and required detail (Lesní lom: 48 points, Hády: 42 points, Šumbera: 56 points, Steinbruch Schmidt: 45 points). The GRS data were collected using a RS-230 Super Spec portable spectrometer (Radiation Solutions, Inc., Canada) with a $2 \times 2^{\prime \prime}\left(103 \mathrm{~cm}^{3}\right)$ bismuthgermanate (BGO) scintillation detector. The assay time was set to $240 \mathrm{~s}$, which is sufficient for carbonate rocks (e.g. Hladil et al. 2006). The counts per second in the selected energy windows were automatically converted to concentrations of K (\%), U (ppm) and Th (ppm) by the instruments. The computed (or "clay") gamma-ray (CGR), which is used as a good proxy of the sum of clay fraction in carbonates, was calculated from the spectral values using 
the formula CGR $[\mathrm{API}]=\mathrm{Th}[\mathrm{ppm}] \cdot 3.93+\mathrm{K}[\%] \cdot 16.32$ (Rider 1999).

Rock samples for bulk MS measurements were collected at 3 (Moravian Karst) to $5 \mathrm{~cm}$ (Steinbruch Schmidt) vertical step intervals and then measured with a laboratory KLY-4S kappabridge (Agico, Czech Republic; magnetic field intensity of $300 \mathrm{Am}^{-1}$, operating frequency of $920 \mathrm{~Hz}$, sensitivity of $\left.4 \cdot 10^{-8} \mathrm{SI}\right)$. Mass-specific MS data expressed in $\mathrm{m}^{3} \cdot \mathrm{kg}^{-1}$ were used. A total of 599 MS samples (Lesní lom: 144 samples, Hády: 146 samples, Šumbera: 162, Steinbruch Schmidt: 147) were measured.

Rock samples used for the MS measurements were pulverised in an agate mortar down to $<63 \mu \mathrm{m}$ fraction. The powder was placed in plastic cells with a Mylar foil bottom and analysed by a Delta Premium (Innov-X, USA) energy dispersive X-ray fluorescence (EDXRF) spectrometer for 240 seconds using the Geochem VANAD mode. The EDXRF data, expressed in counts per seconds (cps), were calibrated by independent inductively coupled plasma mass spectrometry (ICP-MS) analysis (total digestion) of 30 samples by the ACME accredited analytical laboratory, Vancouver, Canada. Linear regression functions of the EDXRF signal (cps) vs. ICP-MS concentrations were used as the calibration equations to convert the cps data to wt $\%$ and $\mathrm{ppm}$, while the correlation coefficients $\left(\mathrm{R}^{2}\right)$ indicated the sensitivity of the EDXRF method (Tab. 1)

\section{Biostratigraphy and facies/microfacies description and interpretation of the Steinbruch Schmidt section}

\section{Biostratigraphy}

At Steinbruch Schmidt, $7.5 \mathrm{~m}$ of Late Devonian cephalopod limestones are exposed including the Lower and Upper Kellwasser Event intervals (LKWI and UKWI, respectively). It is one of the classical localities and many researchers studied the abandoned quarry (e.g. Buggisch 1972; Sandberg et al. 1988; Ziegler \& Sandberg 1990; Schindler 1990a, b; Schülke 1995; Walliser 1996; Casier \& Lethiers 1998; Devleeschouwer et al. 2002; Kaufmann et al. 2004; Pujol et al. 2006; Dopieralska et al. 2016). The section represents former parastratotype for the Fr-Fa boundary (for discussion of the boundary see Klapper et al. 1993). The thickness of the LKWI is up to $0.45 \mathrm{~m}$ and that of the UKWI is up to $0.4 \mathrm{~m}$; the limestones between the LKWI and UKWI measure up to $2.6 \mathrm{~m}$. The age of the strata ranges from the late Lower rhenana Zone to the rhomboidea (= Pa. rhomboidea to Pa. gracilis) Zone. Here, we deal with a succession from close to the top of the Lower rhenana Zone to the Upper triangularis ( $=$ Pa. minuta minuta) Zone. The rocks represent pelagic limestones mostly comprising mudstones and wackestones with less common packstones. Shallow-water fauna (brachiopods, bivalves, crinoids, gastropods, trilobites, corals) is restricted, both environmentally and in numbers whereas pelagic/nektonic elements dominate, including goniatites, orthocone cephalopods, homoctenids, and entomozoaceans. The latter two groups are well preserved in the KW intervals and show mass-occurrences in distinct beds. Relatively abundant lingulid brachiopods and especially "buchiolid" bivalves can be found. Lingulids can easily be transported by drifting, but are also considered to be tolerant to low-oxygen conditions (e.g. Bond \& Zatoń 2003, Marynowski et al. 2011 from lower Famennian strata; Posenato et al. 2014 across the Permian-Triassic boundary). For the group of "buchiolid" bivalves the same holds true - Grimm (1998) who revised many taxa of "Buchiola" even suspected a chemotrophic mode of life, at least for some taxa of the group. Above the Fr-Fa boundary, fossils are much less abundant in the Famennian.

The rocks are extremely rich in condonts; Ziegler \& Sandberg (1990) reported up to 11,200 specimens $/ \mathrm{kg}$ from the linguiformis Zone - the number of conodonts decreases in the Famennian, especially immediately above the UKWI, but is still up to 2,500 per kilogram in the Middle crepida Zone (Schülke 1995). The palmatolepid-polygnathid conodont biofacies dominates - icriodids only increase in number in the final interval of the KW Crisis close to the Fr-Fa boundary (e.g. Sandberg et al. 1988, Ziegler \& Sandberg 1990, Schindler 1990b, Schülke 1995); similar observations have been made in other areas around the Fr-Fa boundary (e.g. in the Polish Holy Cross Mountains by Szulczewski 1989, Matyja \& Narkiewicz 1992, Racki et al. 2002; in the area of the type locality of the Fr-Fa boundary in the French Montagne Noire by Girard 1995, Girard \& Feist 1997). The typical conodonts of the late Frasnian and the early Famennian are present. As it would lead much too far to mention most of the taxa occurring in the time interval under consideration, only a few critical ones shall be highlighted. The data mainly come from the papers of Sandberg et al. (1988), Ziegler \& Sandberg (1990) and Schülke (1995); they studied the conodonts extensively in the Steinbruch Schmidt section for details and preceeding conodont research we refer to these publications.

Characteristic taxa for the Frasnian are ancyrodellids (e.g. Ancyrodella nodosa, Ancyrodella curvata), Palmatolepis rhenana rhenana, Pa. nasuta and Ancyroides tsiensi through the late Lower rhenana to the Upper rhenana to linguiformis zones, and Pa. bogartensis (formerly $P a$. rotunda) in the Upper rhenana and linguiformis zones. The diagnostic taxon of the linguiformis Zone ( $\mathrm{Pa}$. linguiformis) is - unlike in many areas around the globe - abundant in the Steinbruch Schmidt section. After the severe loss of conodont taxa referred to by many authors, a restricted number of taxa carried on in the basal 
Famennian: Palmatolepis triangularis and Pa. subperlobata occur immediately above the Fr-Fa boundary in the Lower triangularis $(=P a$. subperlobata to Pa. triangularis) Zone, $P$ a. delicatula and $P a$. claki enter in the Middle triangularis (= Pa. delicatula platys) Zone; Polygnathus brevilaminus is abundant above the Fr-Fa boundary - only very few specimens are reported from the Upper rhenana Zone (Ziegler \& Sandberg 1990) and the linguiformis Zone (Schülke 1995 - one questionable specimen). Two taxa indicating the short time interval just below and above the Fr-Fa boundary are known from the section: Palmatolepis praetriangularis and Ancyroides ubiquitus - the latter was found in the last limestone bed below the Fr-Fa boundary (Schindler 1990b).

Besides the conodonts, fossils of other faunal groups are present in the Steinbruch Schmidt section, which indicate distinct levels within the Fr-Fa interval. Mass occurrences of Homoctenus ultimus, the last representative of the homoctenid tentaculitoids prior to their disappearance, are known from the black limestone beds of the UKWI and the grey limestones underneath; $H$. tenuicinctus is present in the LKWI (Schindler 1990b). From the basal bed of the Famennian, two specimens of Homoctenus sp. have been recognized in a thin-section; although there is a report from China of homoctenids reaching as high as the Famennian rhomboidea ( $=$ Pa. rhomboidea to Pa. gracilis) Zone - and a dacryoconarid Styliolina specimen even higher (Li 2000), this is one of the rare cases when homoctenids cross the Fr-Fa boundary for a short time (Schindler 1990a, b, 2012; Over 2002 also reported a few specimens of Homoctenus above the Fr-Fa boundary from the Northern Appalachian Basin in New York State). Very good indicators for the position in the lower part of the UKWI are two entomozoacean ostracods: 1) Entomoprimitia kayseri is very abundant in the lower black limestone bed; and 2) E. splendens, a perfect index fossil, is known only from the basal UKWI (Groos-Uffenorde \& Schindler 1990, Schindler 1990b). Both taxa can be traced and correlated over long distances (Schindler 1993); Olempska (2002) reported both taxa from the Polish Holy Cross Mountains. Among the trilobites, some taxa are important to be mentioned - with one exception (see following paragraph), they are not present in the oxygen-depleted Kellwasser Event intervals (KWI) themselves: Palpebralia brecciae can be used to recognize the linguiformis Zone in cases where conodonts are absent wide correlation of the taxon is possible (for details see Feist \& Schindler 1994).

\section{Facies and microfacies}

In the Steinbruch Schmidt section, the pelagic limestones mostly consist of mudstones/wackestones. In particular

\begin{tabular}{|c|c|c|c|}
\hline \multirow{11}{*}{ 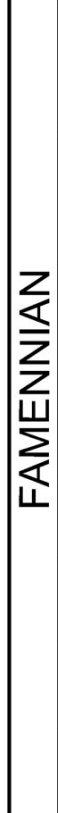 } & $\begin{array}{c}\text { Ziegler } \\
(1962,1969)\end{array}$ & $\begin{array}{c}\text { Ziegler \& } \\
\text { Sandberg } \\
(1990)\end{array}$ & $\begin{array}{c}\text { Spalletta et al. } \\
(2017)\end{array}$ \\
\hline & \multirow[b]{2}{*}{ rhomboidea } & $\begin{array}{l}\text { Late } \\
\text { rhomboidea }\end{array}$ & Palmatolepis gracilis gracilis \\
\hline & & $\begin{array}{l}\text { Early } \\
\text { rhomboidea }\end{array}$ & Palmatolepis rhomboidea \\
\hline & \multirow{2}{*}{$\begin{array}{l}\text { Upper } \\
\text { crepida }\end{array}$} & $\begin{array}{l}\text { Latest } \\
\text { crepida }\end{array}$ & Palmatolepis glabra pectinata \\
\hline & & $\begin{array}{l}\text { Late } \\
\text { crepida }\end{array}$ & Palmatolepis glabra prima \\
\hline & $\begin{array}{l}\text { Middle } \\
\text { crepida }\end{array}$ & $\begin{array}{l}\text { Middle } \\
\text { crepida }\end{array}$ & Palmatolepis termini \\
\hline & $\begin{array}{l}\text { Lower } \\
\text { crepida }\end{array}$ & $\begin{array}{l}\text { Early } \\
\text { crepida }\end{array}$ & Palmatolepis crepida \\
\hline & $\begin{array}{l}\text { Upper } \\
\text { triangularis }\end{array}$ & $\begin{array}{l}\text { Late } \\
\text { triangularis }\end{array}$ & Palmatolepis minuta minuta \\
\hline & $\begin{array}{l}\text { Middle } \\
\text { triangularis }\end{array}$ & $\begin{array}{l}\text { Middle } \\
\text { triangularis }\end{array}$ & Palmatolepis delicatula platys \\
\hline & \multirow{2}{*}{$\begin{array}{l}\text { Lower } \\
\text { triangularis }\end{array}$} & \multirow{2}{*}{$\begin{array}{l}\text { Early } \\
\text { triangularis }\end{array}$} & Palmatolepis triangularis \\
\hline & & & Palmatolepis subperlobata \\
\hline \multirow{3}{*}{ 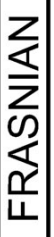 } & & linguiformis & \\
\hline & & $\begin{array}{l}\text { Late } \\
\text { rhenana }\end{array}$ & \\
\hline & & $\begin{array}{l}\text { Early } \\
\text { rhenana }\end{array}$ & \\
\hline
\end{tabular}

Figure 2. Upper Frasnian and lower Famennian conodont zones. Correlation between three lower Famennian conodont zonations of Ziegler (1962, 1969), Ziegler \& Sandberg (1990) and Spalletta et al. (2017) is provided. After Spalletta et al. (2017).

parts of the section, characteristic developments can be observed which may be regarded as 'TimeSpecific Facies' (TSF; e.g. the patterns of the two KWI themselves, the beds below them or the strata right above the UKWI). TSF-phenomena have been introduced by Walliser (1984a, b, 1986) and may be tools for stratigraphic assignment and/or widespread correlation (for further reading and cited literature see Brett et al. 2012). Application of TSF in the Steinbruch Schmidt section has been demonstrated by Schindler (1990b, 1993), Over \& Schindler (2003) and Gereke \& Schindler (2012).

The KWI themselves are developed in a form typical of the pelagic deeper-water settings on submarine rises. The black limestones are enriched in fossils and often display lamination at mm-scale. Benthic fossils are very rare (due to $\mathrm{O}_{2}$-depletion) - probably with the exception of "buchiolid" bivalves and a rare find of a trilobite fragment in the LKWI (Schindler 1993). Concerning the topic of benthic organisms in $\mathrm{O}_{2}$-depleted environments we refer to Rakociński et al. (2016) and literature therein - see also above. 


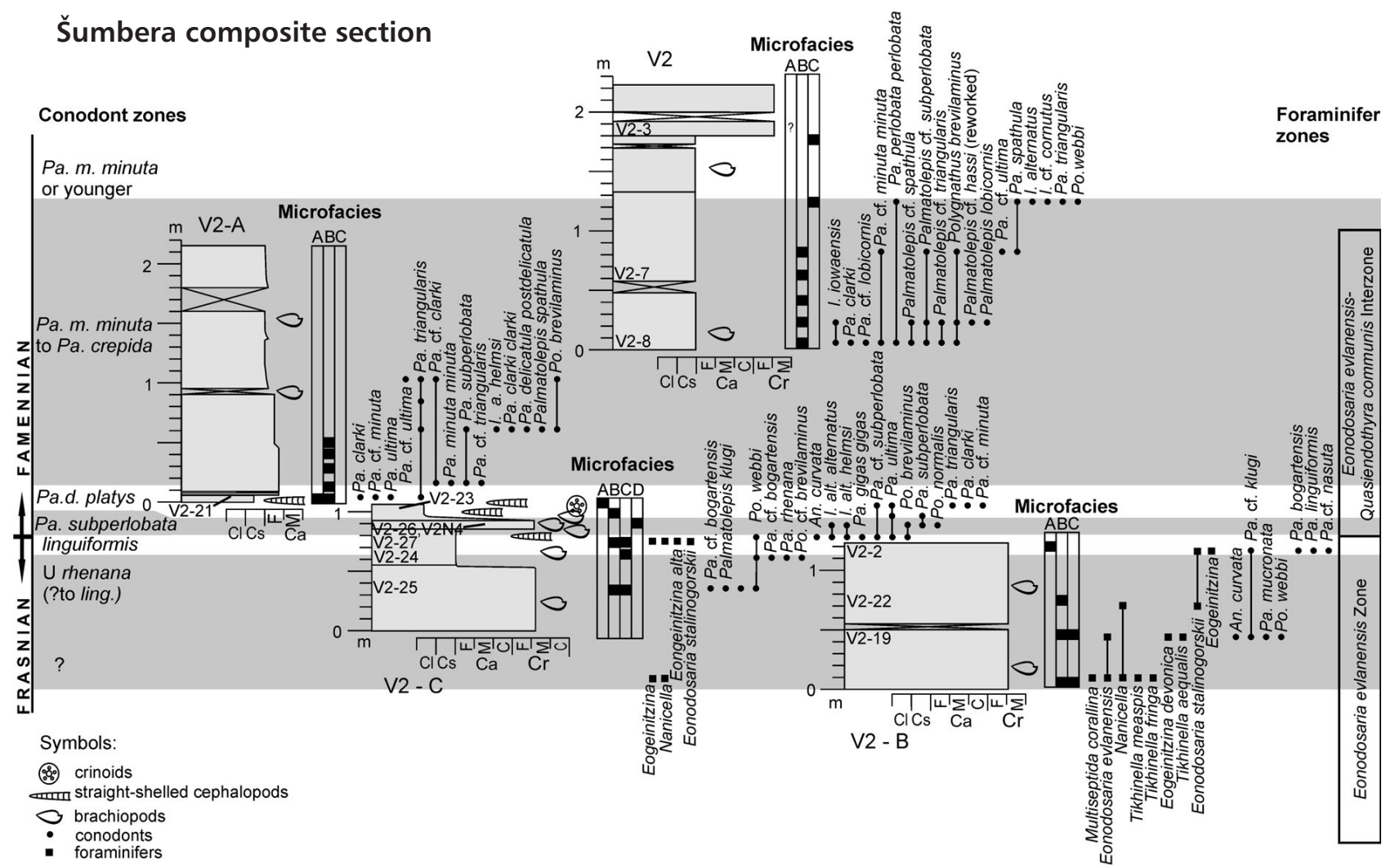

Figure 3. Lithology, microfacies, conodont and foraminifer biostratigraphy of the Sumbera section. Abbreviations: $\mathrm{Ca}-\mathrm{calcarenite}, \mathrm{Cl}-\mathrm{calcilutite}, \mathrm{Cr}$ - calcirudite, Cs - calcisiltite, F - fine-grained, M - medium-grained, C - coarse-grained. Designations "V2-Xx" (e.g. V2-7, V2-22) represent selected conodont and thin-section samples.

\section{Biostratigraphy and facies/microfacies description and interpretation of Moravian Karst sections}

\section{Conodont biostratigraphy}

The Šmbera section is composed of four laterally correlated outcrops (Fig. 3). Frasnian strata about $1.3 \mathrm{~m}$ thick are exposed in the lower part of the succession. Owing to the low number of conodonts recovered, the lowermost part of this interval (below sample V2-19) was assigned to the Upper rhenana or even lower Frasnian zones of the standard conodont zonation (sensu Ziegler \& Sandberg 1990). The overlying strata belong to the Upper rhenana to linguiformis zones as documented by the occurrence of various taxa including Palmatolepis bogartensis, $\mathrm{Pa}$. klugi and $\mathrm{Pa}$. rhenana (samples V2-19, V2-22, V2-24 V2-25). Various polygnathids (e.g. Polygnathus webbi) and ancyrodellids (Ancyrodella curvata) also occur in this interval. The linguiformis Zone (sample V2-2) is documented by rare occurrences of $\mathrm{Pa}$. linguiformis along with more frequent $P a$. bogartensis, $P a$. cf. nasuta and polygnathids. The Fr-Fa boundary is situated within a 0.1 to $0.15 \mathrm{~m}$ thick interval between samples V2-27 and V2-26 (brachiopod co- quina). This interval spans to the upper part of the linguiformis Zone to the Pa. subperlobata Zone. Palmatolepis subperlobata, defining the base of the Famennian (e.g. Klapper 2007, Spalletta et al. 2017), was found in the sample V2-26 and Pa. cf. subperlobata was obtained from the sample V2-27. Other taxa from the sample V2-27 suggest Frasnian age, as documented by $\mathrm{Pa}$. gigas gigas. Various polygnathids (e.g. Polygnathus brevilaminus, Po. webbi), icriodids (Icriodus alternatus) and ancyrodellids (Ancyrodella curvata) were found in this sample.

The Pa. triangularis Zone (sensu Spalletta et al. 2017) seems to be absent or developed in very reduced thickness (below the sampling resolution). The $P a$. subperlobata Zone (sample V2-26) is thus overlain by an approximately 0.25 to $0.3 \mathrm{~m}$ thick interval assigned to $P a$. delicatula platys zone. Various taxa, including Pa. clarki, Pa. triangularis, Pa. subperlobata, Pa. ultima, Pa. cf. minuta, icriodids and polygnathids were recovered here. The overlying interval interpreted as $\mathrm{Pa}$. m. minuta to $\mathrm{Pa}$. crepida Zone (about $2.4 \mathrm{~m}$ thick) yielded various palmatolepids such as Pa. subperlobata, Pa. triangularis, Pa. spathula, $P a$. delicatula postdelicatula, Pa. lobicornis, icriodidis (e.g. Icriodus a. alernatus, I. a. helmsi) and polygnathids (e.g. Po. brevilaminus, Po. webbi). The uppermost part of 


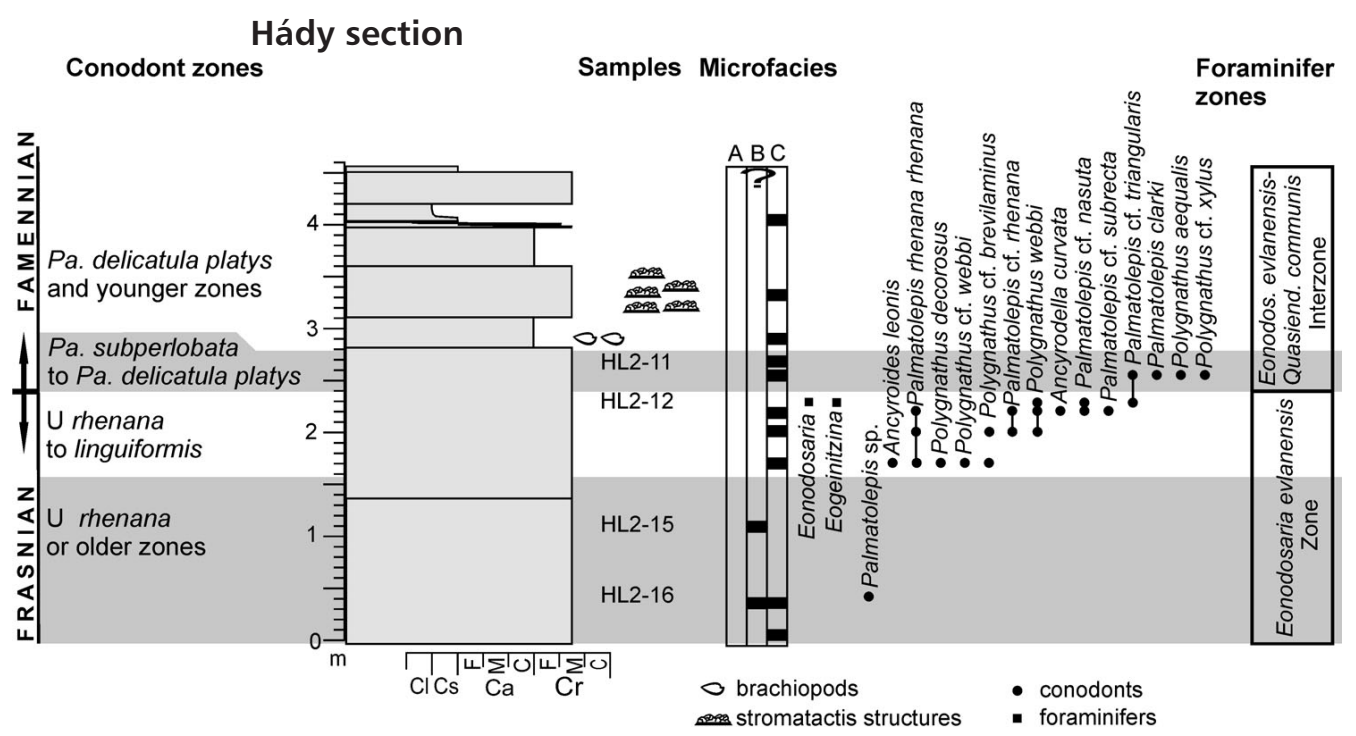

Figure 4. Lithology, microfacies, conodont and foraminifer biostratigraphy of the Hády section. Abbreviations: $\mathrm{Ca}-$ calcarenite, $\mathrm{Cl}-$ calcilutite, $\mathrm{Cr}$ - calcirudite Cs - calcisiltite, F - fine-grained, M - medium-grained, C - coarse-grained. Designations HL2-xx (e.g. HL2-11) represent selected conodont and thin-section samples.

the succession (around $1 \mathrm{~m}$ thick) above Pa. minuta minuta to Pa. crepida Zone thus corresponds to the same or younger zone.

The lowermost part of the Hády section (about $1.6 \mathrm{~m}$ thick) (Fig. 4) yielded relatively poor conodont material (sample HL2-16), which allowed us to identify the Upper rhenana Zone (or older). The overlying interval (about $0.8 \mathrm{~m}$ thick) supposedly represents the rhenana to linguiformis Zone interval. Palmatolepis linguiformis was not recorded in this section, probably because of its rare occurrence in the studied area and even on a worldwide scale in shallower-water facies. Other palmatolepids from this interval include $P a$. rhenana, $P a$. cf. nasuta, $P a$. cf. subrecta, polygnathids (e.g. Po. decorosus, Po. cf. webbi, Po. cf. brevilaminus), Ancyrodella curvata and Ancyroides leonis. It is followed by an interval ( $0.4 \mathrm{~m}$ thick) lacking stratigraphically significant conodonts and typical Frasnian foraminiferal guides, inferred as $P a$. subperlobata to $P a$. delicatula platys Zone. The entry of $P a$. clarki indicated the $P a$. delicatula platys Zone. Various polygnathids (e.g. Po. aequalis, Po. cf. xylus) were also found within this interval. The uppermost part of the section (about $1.8 \mathrm{~m}$ thick) thus corresponds to the $P a$. delicatula platys or younger conodont zones, as suggested by the biostratigraphy of the underlying interval.

The Lesní lom section (Fig. 5) is represented by a 22 m-thick Frasnian succession. The lower and middle part of the section (about $18 \mathrm{~m}$ thick) is tentatively attributed to the Upper rhenana (or older) conodont Zone. This interval yielded various palmatolepids (e.g. Pa. cf. gigas gigas, $\mathrm{Pa}$. cf. juntianensis, $\mathrm{Pa}$. bogartensis), polygnathids (e.g. Po. webbi, Po. politus, Po. cf. brevis), icriodids
(I. alternatus alternatus, I. a. helmsi), ancyrodellids (Ancyrodella curvata) and ancyrognathids (e.g. Ancyrognathus triangularis). The upper part (about $4.5 \mathrm{~m}$ thick) was assigned to the Upper rhenana to linguiformis zones. This interval yielded various conodonts, including palmatolepids $P a$. bogartensis, $P a$. rhenana, $P a$. nasuta, Pa. g. extensa, Pa. hassi, Pa. klugi, Pa. cf. linguiformis, polygnathids (e.g. Po. webbi, Po. brevilaminus, Po. aequalis), Ancyrognathus sp. and Ancyroides leonis.

\section{Foraminiferal biostratigraphy}

In all the studied Moravian sections the uppermost Frasnian Eonodosaria evlanensis Zone was distinguished. The typical associations of multilocular foraminifers are represented by species of Nanicella, Eonodosaria, Frondilina and Tikhinella, which are accompanied by unilocular foraminifers represented by species of Bisphaera, Irregullarina, Parastegnammina and Parathurammina (Hladil et al. 1991, Hladil \& Kalvoda 1993b, Kalvoda 2002). The associations in the lower parts of the Lesní lom and Šumbera sections (Figs 3, 5) are accompanied by Multiseptida corallina which indicates the lower part of the Eonodosaria evlanensis Zone (Kalvoda 2002). However, the vertical septation of chambers that enables the distinction between Multiseptida and Eogeinitzina is often poorly preserved or destroyed by diagenesis, which makes it difficult to fix the last occurrence of Multiseptida.

The uppermost Frasnian association of Eonodosaria, Eogeinitzina, Nanicella and Frondilina provides reliable evidence for the distinction of the Fr-Fa boundary at all 
studied sections (Figs 3-5). The very top of the linguiformis conodont Zone in the Šumbera section (Fig. 3) marks the last occurrence of the above described foraminiferal association indicating that it probably disappeared within the UKWI below or at the Fr-Fa boundary. Foraminifers recorded in the lowermost Famennian are rare and represented by uniloculars, such as Bisphaera sp., Irregullarina sp., Eotuberitina sp., Parastegnammina sp. and Parathurammina sp., which correlate with the Eonodosaria evlanensis-Quasiendothyra communis Interzone defined by Kalvoda (2002).

\section{Facies and microfacies}

A) Mudstones and wacke/packstones/microbial boundstones (Fig. 6A, B). - The macroscopic lithology generally corresponds to calcisiltites to fine-grained calcarenites. Microscopic observation revealed transitions between mudstones and wackestones to packstones, locally with a "clotted" structure.

In the Frasnian part of the Šumbera section, the large intraclasts of the B and C microfacies (see below) are composed of sediment developed as microfacies A. The microfacies was also observed in several restricted stratigraphic intervals in the Famennian part of the Šumbera section (samples V2-21, V2-23, V2-3). In these intervals, the microfacies are locally finely laminated. Very thin (commonly less than $1 \mathrm{~mm}$ ) discontinuous intercalations of peloidal/intraclastic grainstones (B) were locally observed (sample V2-23). Bioclasts are mainly represented by crinoid ossicles, brachiopods, ostracods and girvanellid filaments. In places, current-aligned straight-shelled cephalopod shells were macroscopically observed (sample V2-23). Microfacies observed in places are very similar to "clotted" structures described by Adachi et al. (2004), Hips \& Haas (2006) or Shen \& Webb (2008) and can be thus regarded as microbial boundstones. They are commonly rather blurry and are more clearly developed in protected areas of the microfacies (e.g. under bioclasts or inside of shells).

Intraclastic material of this microfacies A observed in the microfacies B (peloidal/intraclastic/bioclastic packstones to grainstones) contains bioclasts, such as echinoderms, ostracods, girvanellids and peloids.

In the Hády section, the microfacies A was observed in thin-section in the uppermost Frasnian (in intraclastic material), close to the Fr-Fa boundary (sample HL2-12). Here, allochems are composed of crinoids, moravamminids, peloids, ostracods, foraminifers, microproblematics and girvanellids. The "clotted" structure is locally present, reflecting the microbial origin (microbial boundstone). The microfacies is common in intraclasts of the microfacies $\mathrm{C}$ (intraclast rudstones) in various stratigraphic levels across the section.
In the Lesní lom section, the microfacies $\mathrm{A}$ is present in the middle and upper part of the section (Fig. 5). Allochems include: unidentifiable mollusc fragments, ostracods, crinoids, foraminifers, microproblematics, calcispheres, girvanellid filaments, Rothpletzella, brachiopods, moravamminids, gastropods, peloids, bryozoans and trilobites. Some crinoids show bioerosion and/or micrite envelopes. Peloids are relatively common. Locally present "clotted" structure suggests the microbial origin of the microfacies. Locally present cracks in microbialites were infilled by younger microbialites. Some samples from the uppermost part (Upper rhenana to linguiformis zones) of the Lesní lom section contain common sponge spicules (LLB 0, LLB 0,25, LLB 1,3). The sample NLL 16,5 is characterized by the common presence of large corals.

B) Peloidal/intraclastic/bioclastic packstones to grainstones (locally with transitions to rudstones) (Fig. 6C, D). Based on macroscopic observation, this microfacies corresponds to massive calcarenites. Microscopically, packstones to grainstones with somewhat variable content of peloids, intraclasts and bioclasts were observed. The origin of peloids and the differentiation between peloids and similar-sized intraclasts is often problematic. In some cases the peloids are represented by abundant micritized renalcids. The blocky sparite prevails, whereas radiaxial fibrous sparite is infrequently present. The fragmentation of bioclasts and locally developed grading probably reflect the deposition above the storm wave base.

In the Šumbera section, the microfacies locally show normal or inverse grading in micro-scale. Skeletal allochems, mainly represented by brachiopods and echinoderms, are relatively rare, with the exception of several parts, which are enriched in biota. Brachiopods are often fragmented; complete articulated shells are rare. Echinoderms are represented by fragmented or unfragmented crinoid ossicles, sometimes affected by bioerosion and micritization (micrite envelopes). Other biota include renalcids, isolated girvanellid filaments, foraminifers, ostracods, conodonts, gastropods and various microproblematics. In rare instances, brachiopods form nuclei of oncoids (Fig. 6D). The oncoid cortexes consist of girvanellids, Allonema and Rothpletzella. "Clotted" structure is locally present in packstone areas, which suggest a microbial origin. Intraclasts, $\mathrm{mm}$ - to $\mathrm{cm}$-sized, occur principally in the Frasnian part of the section. These intraclasts are composed of the microfacies A (see above) with locally developed "clotted" strucuture (A). Locally, it is possible to classify the larger intraclasts as reworked microbial boundstones.

In the Hády section, the microfacies B is less common in the lower part of the section corresponding to the Upper rhenana or older conodont Zone (samples HL2-15, HL2-16). Bioclasts are represented by: crinoids, peloids, 

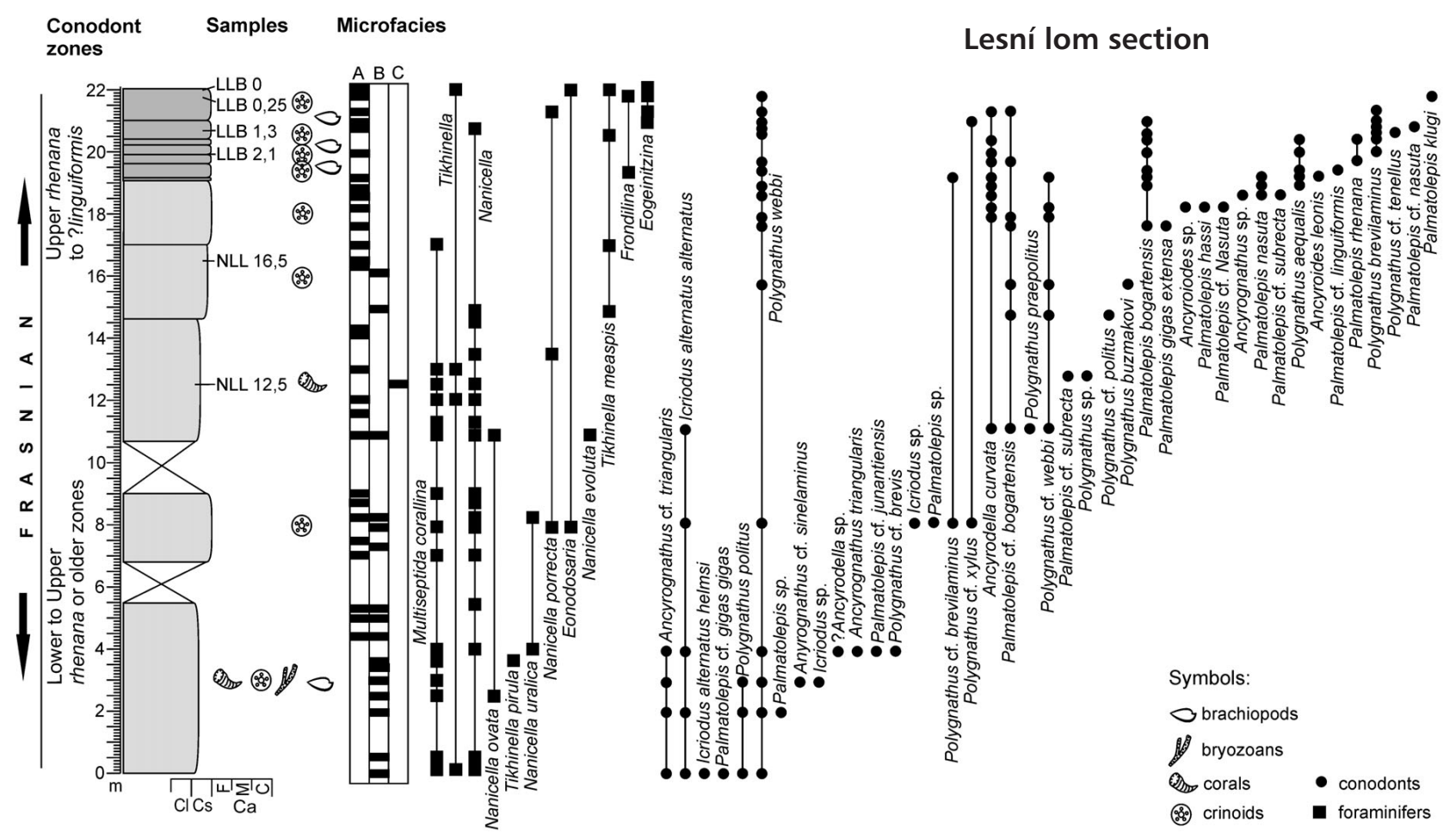

Figure 5. Lithology, microfacies and conodont biostratigraphy of the Lesní lom section. The entire succession corresponds to the Eonodosaria evlanensis foraminifer Zone. Abbreviations: $\mathrm{Ca}$ - calcarenite, $\mathrm{Cl}$-calcilutite, $\mathrm{Cs}$ - calcisiltite, $\mathrm{F}$ - fine-grained, $\mathrm{M}$ - medium-grained, $\mathrm{C}$ - coarse-grained. Designations "NLL xx" and "LLB xx" (e.g. LLB 2,1 or NLL 12,5) represent selected conodont and thin-section samples.

foraminifers, microproblematics, calcispheres, ostracods, renalcids, moravamminids and corals.

The microfacies B is dominant, especially in the lower part, while it is also present in the middle part of the Lesní lom section. Skeletal debris is mostly represented by echinoderms, moravamminids and, locally, mollusc fragments. Unlike the Šumbera and Hády sections, this microfacies often contains large corals in Lesní lom. Other bioclasts include: ostracods, brachiopods, foraminifers, stromatoporoids, microproblematics, bryozoans, girvanellids and moravamminids, some of them with micritic envelopes.

C) Intraclast rudstones (Fig. 6E, F). - This microfacies macroscopically corresponds to limestone breccias (calcirudites). Microscopic observation revealed large intraclasts surrounded by pack- to grainstone-matrix composed of microfacies B (peloidal/intraclastic/bioclastic packstones to grainstones). The large $\mathrm{cm}$-sized intraclasts, composed of the microfacies A, are often elongated and angular to subangular, suggesting very short transport. Normal and inverse grading was locally observed.

In the Šumbera section, intraclast rudstones occur, especially in the Frasnian part. Skeletal allochems are represented by fragmented echinoderms (crinoids), brachiopods, girvanellids, moravamminids, foraminifers, tabulate and rugose corals, udoteacean and solenoporacean algae, bryozoans, Rothpletzella and ichthyoliths. A specific sub- type of this microfacies locally contains relatively abundant udoteacean algae (sample V2-19). Stromatactis was locally observed. Some peloids are obviously strongly micritized renalcids.

In the Hády section, the rudstones are present across the entire succession. Bioclasts are represented by: brachiopods, corals, gastropods, foraminifers, calcispheres, microproblematics, ostracods, conodonts and ichthyoliths. Intraclasts are mainly represented by "clotted" wacke/packstones of the microfacies A with various bioclasts (e.g. echinoderms, brachiopods, moravamminids, calcispheres, ostracods) and, partly by peloidal/intraclast grainstones. Stromatactis structures are abundant in higher parts of the section.

In the Lesni lom section, the intraclast/peloidal rudstone was only observed in the sample NLL 12,5. Allochems are represented by ostracods, brachiopods, gastropods and peloids. Large intraclasts are represented by mudstones, wacke/packstones and microbial boundstones with a "clotted" structure of the microfacies A. Biota in the intraclastic material include ostracods, gastropods, calcispheres, foraminifers and Rothpletzella.

D) Brachiopod rudstone (Fig. 6G, H). - This microfacies is restricted to a single bed approximately $5 \mathrm{~cm}$ thick at the Šmbera section (sample V2N4, assumed as Lower triangularis Conodont Zone). It is characterized by large 
articulated and fragmented brachiopods surrounded by blocky and radiaxial fibrous sparite and spaces infilled by intraclast/peloidal grainstones (microfacies B). Large complete brachiopod shells are often filled with cement or peloidal/intraclastic grainstone with fragmented brachiopods and echinoderms. Blocky and radiaxial fibrous sparite cements were also observed in some brachiopod infills. The fragmentation and chaotic arrangement of brachiopods suggests hydrodynamic transport possibly during a storm event.

\section{Environmental comparison of Steinbruch Schmidt and Moravian Karst sections}

Combined observations of sedimentology/facies and fossil content show that the Steinbruch Schmidt succession has been deposited in significantly deeper water than the sediments from the Moravian Karst sections. In Steinbruch Schmidt barely any intraclasts, no coquinas of benthic organisms and no stromatactis features are present. However, hardgrounds are developed in some of the beds (e.g. in the marker bed below the UKWI - see Schindler 1993, Gereke \& Schindler 2012) and intense bioturbation is present.

The rocks of the Steinbruch Schmidt section were deposited on a submarine rise surrounded by relatively deeper basinal areas (e.g. Schmidt 1925, 1935; Rabien 1956; Meischner 1971) whereas the Moravian Karst sections were deposited in a carbonate ramp environment (Hladil 1991). The Steinbruch Schmidt section belongs to the Rhenohercynian Belt and comprises cephalopod limestone facies (e.g. Tucker 1974, Tucker \& Wright 1990). The cephalopod limestones - as well as the embedded Kellwasser intervals - are often very condensed. For the Kellwasser intervals this reduced thickness can be observed e.g. in the Kellwasser type locality in the Kellwasser Valley of the Harz Mountains (e.g. Gereke \& Schindler 2012, Gereke et al. 2014) or in the Sessacker Trench section in the Dill Syncline of the Rheinisches Schiefergebirge (e.g. Schindler et al. 1998). The thickness of the Kellwasser sediments may vary significantly, from one bed of 0.1 to $0.2 \mathrm{~m}$ (e.g. Hühnerbach Valley, Sessacker
Trench section) to almost $1 \mathrm{~m}$ (Aeke Valley) (compare e.g. Schindler 1988, 1990b, 1993; Gereke \& Schindler 2012).

Deposition of intraclastic rudstones in Šumbera and particularly Hády sections and occurrence of Frasnian continental basal clastics in the near vicinity (Štelcl 1969, Krmíček 2006) suggest rather shallower environment possibly in the proximal part of a carbonate ramp. The Lesní lom section is generally characterized by thicker and more fine-grained sediments (mudstones to grainstones), which probably reflect a relatively more distal position to the shore than in the case of Šumbera and Hády sections.

The basic differences between the pelagic limestones in the Steinbruch Schmidt section and the limestones of the Moravian Karst deposited on a wide carbonate ramp are mainly recognisable in respect to the fossil content and the sedimentary features. Whereas in the Kellerwald area fossils of the pelagic offshore realm dominate (e.g. dacryoconarids, homoctenids, goniatites, straight-shelled cephalopods, entomozoacean ostracods), the Moravian Karst sections yield a variety of shallow-water organisms (e.g. brachiopods, bryozoans, benthic foraminifers, corals, crinoids, trilobites as well as different kinds of algae); peloids, bioeroded shells and coquinas of fragmented shells are also present. The prevailing carbonates in the Steinbruch Schmidt section are mud- and wackestones whereas in the Moravian Karst grainstones, packstones, rudstones and even breccias are frequent. In summary, there is a low-energy deeper-water facies in the Steinbruch Schmidt section and successions of high-energy shallow-water facies in the Moravian Karst.

\section{Gamma-ray spectrometry}

The basic statistics of the measured gamma-ray values are presented in Tab. 1 and all measured values are in Table I in the electronic supplementary appendix. The CGR values vary from 0.8 to 49.8 API. Relatively high values were measured in the pelagic limestones of the Steinbruch Schmidt section, whereas much lower values are typical for sections in the Moravian Karst (Fig. 7; Tab. 1). The highest covariance with the total dose rate was found for $K\left(R^{2}=0.82\right)$ in Steinbruch Schmidt. This suggests that K mainly drives the

Figure 6. Thin-section microphotographs (A-D, F, H) and photographs of polished slabs (E, G) illustrating representative examples of the microfacies described in the text. • A, B - microfacies A; A - mudstone to wackestone with blurry "clotted" structure, larger cephalopod and fragmented bioclasts are present, Šumbera section (sample V2-23); B - burrowed wackestone with fragmented bioclasts, Lesní lom section (sample LLB 2,1). • C, D - microfacies B; C - laminated peloidal/intraclastic packstone to grainstone, Š umbera section (sample V2-7); D - peloidal/intraclast/bioclastic grainstone to rudstone with oncoids, Šumbera section (sample V2-19). E, F - microfacies C; E - rudstone with large intraclasts, Šumbera section (sample V2-27); F - intraclast rudstone (microfacies C) composed of "clotted" microbial mudstone or wackestone intraclasts (microfacies A) surrounded by intraclast/peloidal/bioclastic grainstone (generally corresponding to microfacies B), Hády section (sample HL2-11). • G-H microfacies D; G - accumulation of large brachiopods, Sumbera section (sample V2-26/V2N4); H - brachiopods with infills of intraclast/peloidal grainstone or blocky and radiaxial fibrous cement, Šumbera section (samples V2-26/V2N4). $\bullet$ Scale bars for A-D, F, H 5 mm; scale bars for E, G 10 mm. 

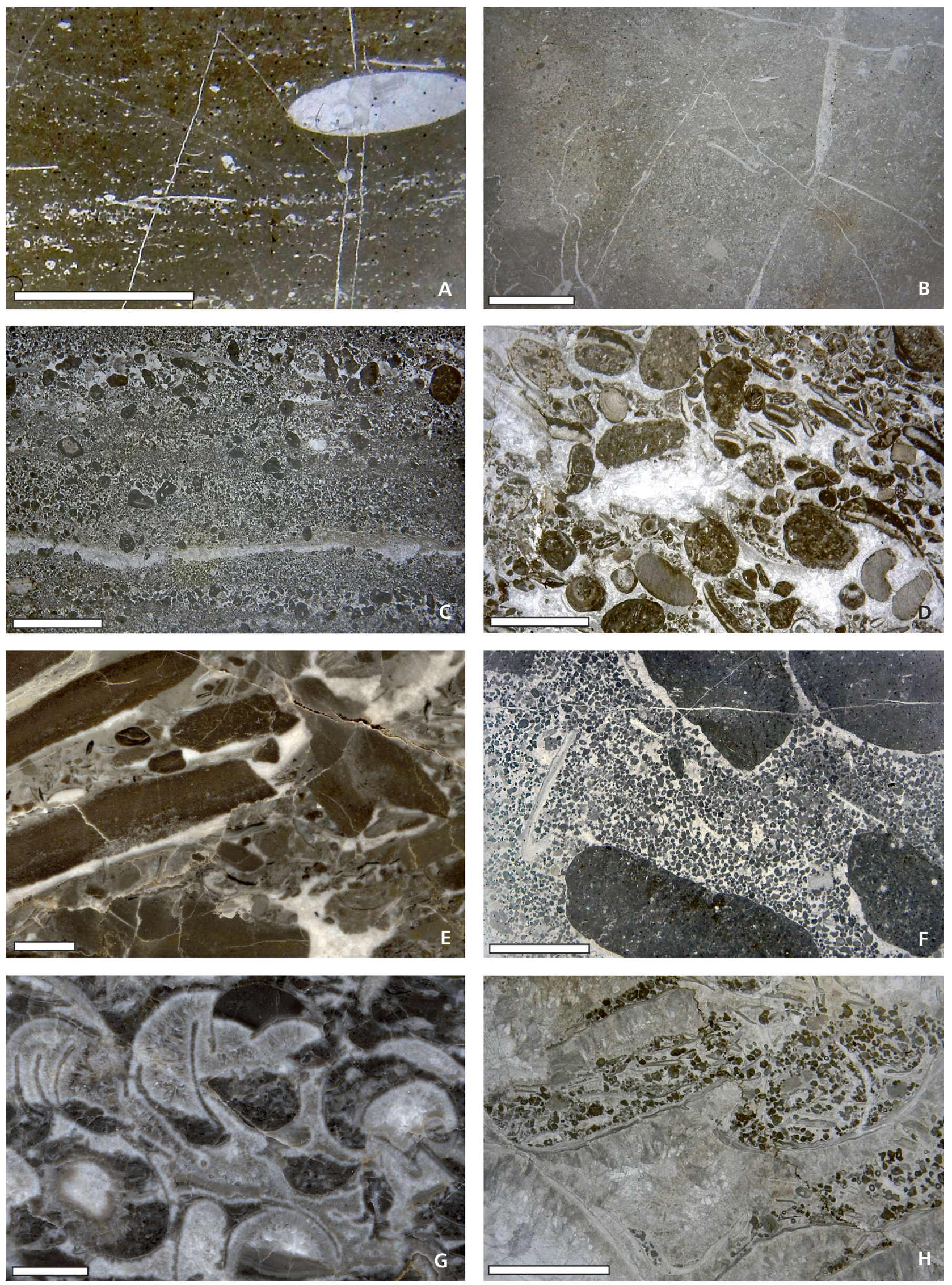
Table 1. Calibration equations used for conversion of XRF signal (cps) to ICP-MS oxide and element concentrations (wt\%, ppm).

\begin{tabular}{llc}
\hline Oxide/element & Calibration equation & $\mathrm{R}^{2}$ \\
\hline $\mathrm{SiO}_{2}$ & $\mathrm{SiO}_{2}(\mathrm{wt} \%)=0.0002 \times \mathrm{Si}(\mathrm{cps})+0.0771$ & 0.990 \\
$\mathrm{Al}_{2} \mathrm{O}_{3}$ & $\mathrm{Al}_{2} \mathrm{O}_{3}(\mathrm{wt} \%)=0.0002 \times \mathrm{Al}(\mathrm{cps})+0.2671$ & 0.991 \\
$\mathrm{CaO}$ & $\mathrm{CaO}(\mathrm{wt} \%)=0.0001 \times \mathrm{Ca}(\mathrm{cps})+3.0784$ & 0.998 \\
$\mathrm{Fe}_{2} \mathrm{O}_{3}$ & $\mathrm{Fe}_{2} \mathrm{O}_{3}(\mathrm{wt} \%)=0.0001 \times \mathrm{Fe}(\mathrm{cps})+0.0348$ & 0.994 \\
$\mathrm{~K}_{2} \mathrm{O}$ & $\mathrm{K}_{2} \mathrm{O}(\mathrm{wt} \%)=0.0001 \times \mathrm{K}(\mathrm{cps})+0.1664$ & 0.996 \\
$\mathrm{TiO}_{2}$ & $\mathrm{TiO}_{2}(\mathrm{wt} \%)=0.0001 \times \mathrm{Ti}(\mathrm{cps})-0.0298$ & 0.992 \\
$\mathrm{MnO}$ & $\mathrm{MnO}(\mathrm{ppm})=0.0001 \times \mathrm{Mn}(\mathrm{cps})-0.0056$ & 0.993 \\
$\mathrm{Rb}_{\mathrm{Sr}}$ & $\mathrm{Rb}(\mathrm{ppm})=0.9707 \times \mathrm{Rb}(\mathrm{cps})-0.311$ & 0.999 \\
$\mathrm{Zr}$ & $\mathrm{Sr}(\mathrm{ppm})=1.2185 \times \mathrm{Sr}(\mathrm{cps})-12.171$ & 0.996 \\
$\mathrm{Cu}$ & $\mathrm{Zr}(\mathrm{ppm})=1.1708 \times \mathrm{Zr}(\mathrm{cps})-4.8282$ & 0.997 \\
$\mathrm{~Pb}$ & $\mathrm{Cu}(\mathrm{ppm})=0.7812 \times \mathrm{Cu}(\mathrm{cps})-5.1203$ & 0.983 \\
$\mathrm{Zn}$ & $\mathrm{Pb}(\mathrm{ppm})=0.9996 \times \mathrm{Pb}(\mathrm{cps})-2.7427$ & 0.999 \\
\hline & $\mathrm{Zn}(\mathrm{ppm})=0.8444 \times \mathrm{Zn}(\mathrm{cps})-5.7096$ & 0.989 \\
\hline
\end{tabular}

gamma-ray signal, which is usually contained in detritic components, such as clay minerals, micas and K-feldspars (Rider 1999, Doveton \& Meriam 2004). The second important source of the gamma-ray signal in the Steinbruch Schmidt is uranium (dose rate $v s . \mathrm{U}: \mathrm{R}^{2}=0.75$ ), which is usually carried by detritic heavy minerals, authigenic phosphates and organic matter (Rider 1999, Doveton \& Meriam 2004, Lüning et al. 2004). The LKWI and UKWI are characterized by higher CGR, $\mathrm{U}$ and $\mathrm{U} / \mathrm{Th}$ values (U/Th 0.6 in the LKWI; 0.85 in the UKWI) in the Steinbruch Schmidt. U/Th values vary between low values $(0-0.74)$ in nodular limestones and relatively higher values $(0.75-0.85)$ in the LKWI and UKWI (Fig. 7), which are indicative of oxic and hypoxic conditions, respectively (e.g. Jones \& Manning 1994, Marynowski et al. 2012, Rakociński et al. 2016). Values continue to be relatively high up to the "post-event" intervals while a second weaker U and CGR peak, related to thin shaly intercalations, occurs above both event intervals.

In the Moravian Karst, $\mathrm{U}$ has the highest statistical correlation with total dose rate $\left(\mathrm{R}^{2}=0.78-0.98\right)$ as compared with $\mathrm{K}$ and Th (Tab. 2). In general, U/Th values are high (0.8-12.7) in the Moravian Karst sections, owing to the relatively low $\mathrm{Th}$ and relatively high $\mathrm{U}$ concentrations (Tab. 2; Fig. 7). An interval with two peaks of U concentrations and relatively high CGR values occurs in the uppermost Frasnian limestones (Upper rhenana to linguiformis biozones) at the Lesní lom and Hády sections. Based on the biostratigraphic position and the gamma-ray signal these two horizons can be correlated with LKWI and UKWI from the Steinbruch Schmidt (Fig. 8).

\section{Bulk magnetic susceptibility}

Median MS values for each section are reported in Tab. 2 and all measured values are in Table II in the electronic supplementary appendix. Samples from the Steinbruch Schmidt have the highest values; the Hády and Šumbera sections have lower values and the lowermost mean values come from the Lesní lom section. Our MS curve of the Steinbruch Schmidt section corresponds in high detail with the MS curves published by Crick et al. (2002) and Riquier et al. (2009; correlation is less straightforward due to lower number of samples), which illustrates a good reproducibility of the MS data. MS is generally high in the interval from the base of the section (Lower rhenana conodont Zone) to the upper part of the Upper rhenana conodont Zone (1 m above LKWI) (Fig. 7). MS within the LKWI is highly variable, ranging from very high to very low values (both in shale and limestone beds). Upper parts of the Upper rhenana and the lower portions of the linguiformis conodont zones are characterized by lower values, which again increase at the base of the UKWI. Maximum MS values are observed within and just above the UKWI. In general, MS is relatively high in the Famennian and displays two cycles (Fig. 7).

The MS curve of the Hády section shows several correlative features with the Steinbruch Schmidt curve. Two levels with increased MS values occur just below the Fr-Fa boundary (Upper rhenana to linguiformis conodont zones) corresponding to the GRS-based equivalents of the LKWI and UKWI (Fig. 7). There is no distinct MS record in the Kellwasser Crisis interval in the Lesní lom and Šumbera sections, although the uppermost Frasnian parts have generally higher values compared to the underlying succession (Fig. 7). MS values markedly increase in the upper part of the Famennian at the Hády (from Palmatolepis delicatula platys or higher conodont zones) and Šumbera section (Pa. minuta minuta or younger zone).

\section{Element geochemistry}

Median values of major and trace element concentrations for each section are listed in Tab. 3 and all measured values

Figure 7. Key curves of petrophysical (CGR, U, U/Th, MS) and geochemical $\left(\mathrm{SiO}_{2}, \mathrm{Rb}, \mathrm{TiO}_{2}, \mathrm{CaO}, \mathrm{Zr} / \mathrm{Rb}, \mathrm{Pb}, \mathrm{Fe} 2 \mathrm{O} 3\right)$ proxies from the studied Rheinisches Schiefergebirge (Steinbruch Schmidt) and Moravian Karst (Hády, Šmbera, Lesní lom) sections. Conodont zones in Steinbruch Schmidt after Feist \& Schindler (1994); *bed numbers from Schindler (1990). < LOD = below limit of detection. Abbreviations: rhe - rhenana, lin - linguiformis, su - Pa. subperlobata, tr-Pa. triangularis, pl-Pa. delicatula platys, min - Pa. minuta minuta, crepida - Pa. crepida, L - lower, U - Upper, St. - stage, C.z. - Conodont zone, M. - metres, S. - sub-section of composite section; $\mathrm{U}_{\mathrm{GRS}}$ - gamma-ray measured U, $\mathrm{U}_{\mathrm{ICP}}-\mathrm{ICP}-\mathrm{MS}$ measured U. 
Tomáš Weiner et al. • An Integrated Stratigraphy of the Frasnian-Famennian Boundary Interval

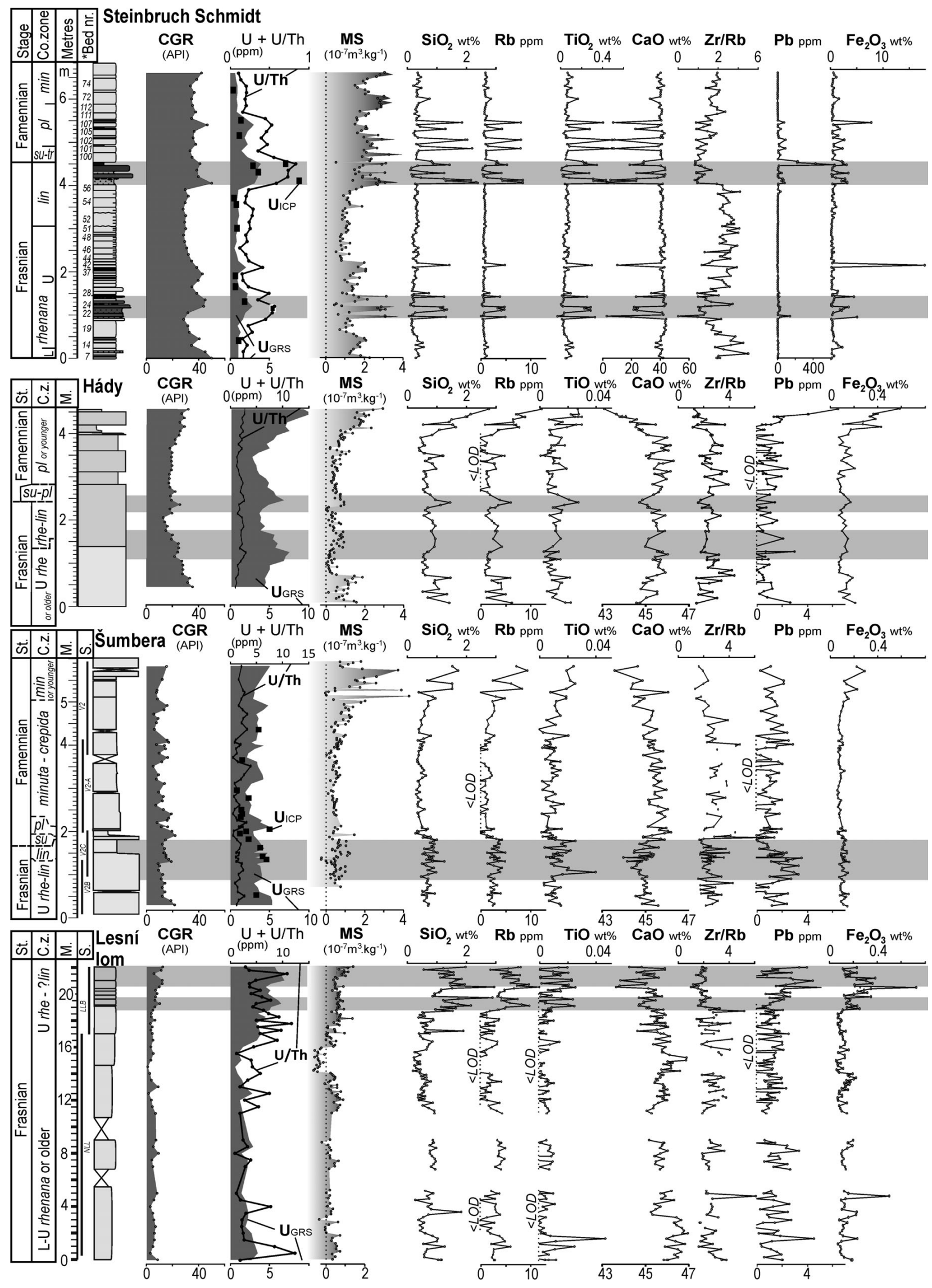




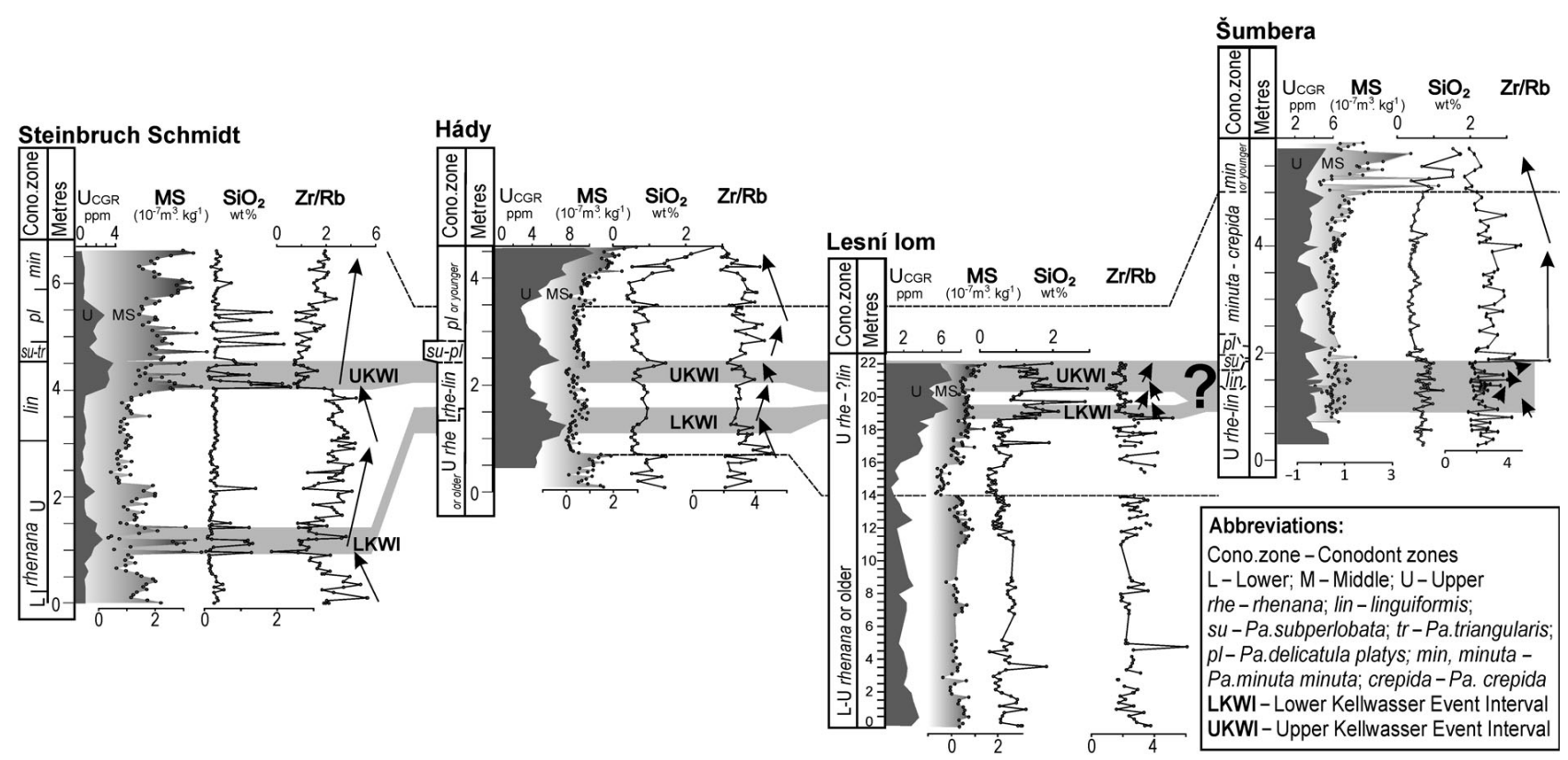

Figure 8. Correlation of the studied Moravian Karst and Rheinisches Schiefergebirge Fr-Fa sections based on the conodont biostratigraphy and $\mathrm{U}$ gamma-ray, magnetic susceptibility, $\mathrm{SiO}_{2}$ and $\mathrm{Zr} / \mathrm{Rb}$ logs. Correlative trends of the $\mathrm{Zr} / \mathrm{Rb}$ curves are marked by arrows.

Table 2. Median (med), minima ( $\mathrm{min}$ ) and maxima (max) of gamma-ray spectrometry and magnetic susceptibility values and covariance between total dose rate (TOT) and $\mathrm{U}, \mathrm{K}$ and $\mathrm{Th}$ for each of the studied sections.

\begin{tabular}{|c|c|c|c|c|c|c|c|c|c|c|c|}
\hline & & CGR & $\mathrm{K}$ & $\mathrm{U}$ & Th & $\mathrm{U} / \mathrm{Th}$ & TOT:U & TOT:K & TOT:Th & $\mathrm{Th} / \mathrm{K}$ & MS \\
\hline & units & API & $\%$ & ppm & $\mathrm{ppm}$ & & $\mathrm{R}^{2}$ & $\mathrm{R}^{2}$ & $\mathrm{R}^{2}$ & $\mathrm{R}^{2}$ & \\
\hline \multirow{3}{*}{ Steinbruch Schmidt $(\mathrm{n}=45)$} & $\min$ & 28.1 & 0.8 & 0.5 & 3.4 & 0.1 & & & & & $4.21 \cdot 10^{-8}$ \\
\hline & med & 34.9 & 1.1 & 1.0 & 4.4 & 0.2 & 0.8 & 0.8 & 0.3 & 0.4 & $1.67 \cdot 10^{-7}$ \\
\hline & $\max$ & 49.8 & 1.8 & 3.9 & 6.0 & 0.8 & & & & & $3.9 \cdot 10^{-7}$ \\
\hline \multirow{3}{*}{ Hády $(\mathrm{n}=42)$} & $\min$ & 12.8 & 0.4 & 2.6 & 1.5 & 1.0 & & & & & $6.25 \cdot 10^{-10}$ \\
\hline & med & 21.8 & 0.7 & 4.8 & 2.5 & 2.1 & 0.9 & 0.4 & 0.5 & 0.7 & $5.76 \cdot 10^{-8}$ \\
\hline & $\max$ & 35.3 & 1.2 & 10.1 & 4.0 & 3.0 & & & & & $2.98 \cdot 10^{-7}$ \\
\hline \multirow{3}{*}{ Šumbera $(\mathrm{n}=56)$} & $\min$ & 6.8 & 0.1 & 2.0 & 0.9 & 0.3 & & & & & $-3 \cdot 10^{-8}$ \\
\hline & med & 14.3 & 0.4 & 3.6 & 2.2 & 0.6 & 0.8 & 0.3 & 0.4 & 0.4 & $5.17 \cdot 10^{-8}$ \\
\hline & $\max$ & 23.1 & 0.5 & 5.4 & 3.8 & 1.3 & & & & & $4.92 \cdot 10^{-7}$ \\
\hline \multirow{3}{*}{ Lesní lom (n = 48) } & $\min$ & 0.8 & 0.0 & 0.9 & 0.2 & 1.1 & & & & & $-6.7 \cdot 10^{-8}$ \\
\hline & med & 5.4 & 0.1 & 3.2 & 0.8 & 4.4 & 1.0 & 0.4 & 0.3 & 0.4 & $3.92 \cdot 10^{-8}$ \\
\hline & $\max$ & 12.4 & 0.4 & 7.2 & 1.9 & 12.7 & & & & & $1.41 \cdot 10^{-7}$ \\
\hline
\end{tabular}

Table 3. Median values of selected oxides and elements measured by XRF and calibrated by independent ICP-MS analysis. * $\mathrm{SiO}_{2}$ and $\mathrm{K}_{2} \mathrm{O}$ concentrations are below detection limits in prevailing number of samples from the Moravian Karst and the median was calculated just from few samples with detectable (considerably higher) values.

\begin{tabular}{|c|c|c|c|c|c|c|c|c|c|c|c|c|}
\hline Sections & $\mathrm{Al}_{2} \mathrm{O}_{3}$ & $\mathrm{SiO}_{2}$ & $\mathrm{~K}_{2} \mathrm{O}$ & $\mathrm{TiO}_{2}$ & $\mathrm{CaO}$ & $\mathrm{Fe}_{2} \mathrm{O}_{3}$ & $\mathrm{MnO}$ & $\mathrm{Zr}$ & $\mathrm{Rb}$ & $\mathrm{Sr}$ & $\mathrm{Pb}$ & $\mathrm{Zn}$ \\
\hline & \multicolumn{6}{|c|}{$\mathrm{wt} \%$} & \multicolumn{6}{|c|}{$\mathrm{ppm}$} \\
\hline Steinbruch Schmidt $(\mathrm{n}=147)$ & 2.3 & 6.5 & 0.5 & 0.1 & 41.0 & 0.5 & 0.1 & 39.3 & 16.6 & 248.3 & 5 & 8.7 \\
\hline Hády $(\mathrm{n}=146)$ & $0.7 *$ & 0.7 & $0.2^{*}$ & 0.01 & 45.4 & 0.1 & 0.01 & 2.2 & 2.0 & 286.1 & 0.7 & 5.4 \\
\hline Šumbera $(n=162)$ & $0.5^{*}$ & 0.6 & $0.2 *$ & 0.01 & 45.2 & 0.1 & 0.01 & 2.3 & 2.0 & 233.5 & 1.1 & 5.5 \\
\hline Lesní lom $(\mathrm{n}=144)$ & $0.6^{*}$ & 0.8 & $0.2^{*}$ & 0.01 & 45.7 & 0.1 & 0.01 & 3.9 & 2.7 & 204.7 & 4.0 & 6.2 \\
\hline
\end{tabular}



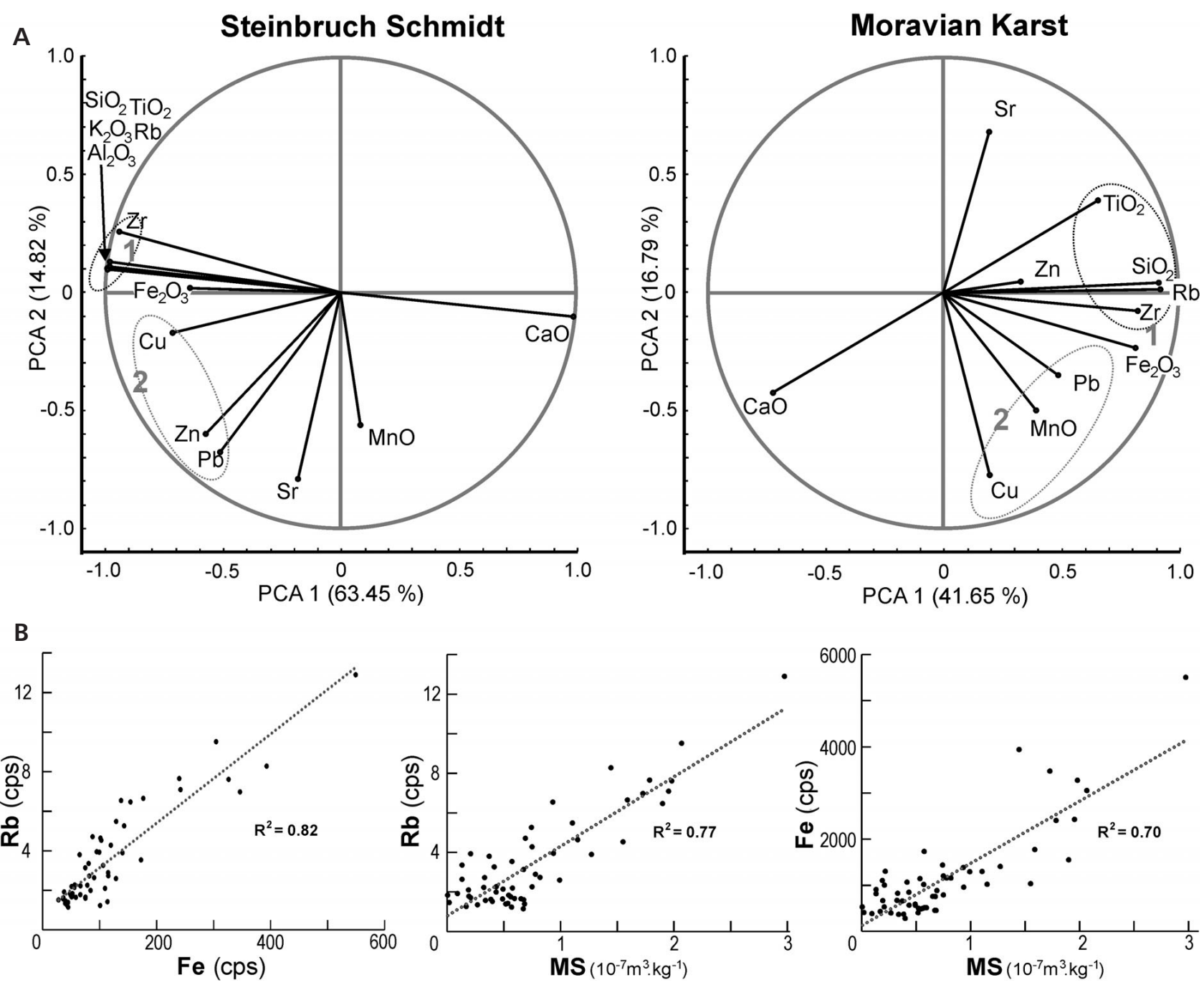

Figure 9. A - principal component analysis of the XRF data from the studied sections. $\bullet$ B - bivariate plots of the magnetic susceptibility and XRF measured non-calibrated Rb and Fe values (cps units) from the Hády section. Statistical correlation is very poor between MS and Rb or Fe in other studied sections.

are in Table III in the electronic supplementary appendix. Median concentrations of measured elements markedly differ between the Moravian Karst sections and Steinbruch Schmidt (Tab. 3). The concentrations of typically terrigenous detrital elements, such as Al, K, Ti, Zr and Rb are about two- to one-order of magnitude lower in the pure shallow-marine limestone facies from the Moravian Karst as compared with the deeper-marine nodular and black limestones, marlstones and shales from Steinbruch Schmidt (see Tab. 3). The $\mathrm{Al}_{2} \mathrm{O}_{3}$ concentrations are below the detection limits (DL) of the XRF device in the prevailing number of samples (Lesní lom: 107 samples < DL/44 samples > DL; Hády 63/23; Šumbera 95/11) from the Moravian Karst; therefore they were applied in normalisation only when the measured data made it possible. Consequently, the target element concentrations were normalised to $\mathrm{Rb}$, which is an alternative refractory terrigenous element considered a conservative proxy of clay-sized detrital fractions in sediments (e.g. Schulte \& Speijer 2009, Jones et al. 2012). Normalizations to $\mathrm{Rb}$ or $\mathrm{Al}$ are used to eliminate the dilution effect of quartz and carbonate minerals due to variable grain size and rate of carbonate production in marine depositional settings (e.g. Brumsack 2006), although pitfalls are related to this approach (see Van der Weijden 2002).

Principal Component Analysis (PCA) revealed several groups of elements, which show similar geochemical affinities and behaviour in our XRF dataset (Fig. 9a). Group 1 represents elements usually related to detrital terrigenous fraction in sediments, $\mathrm{Al}, \mathrm{Si}, \mathrm{K}, \mathrm{Ti}, \mathrm{Zr}$ and $\mathrm{Rb}$, both for the Moravian Karst sections and Steinbruch Schmidt (Fralick \& Kronberg 1997, Rachold \& Brumsack 2001, Niebuhr 2005, Sageman \& Lyons 2005, Śliwiński et al. 2010, Whalen et al. 2015, Bábek et al. 2016). Data from the 
Moravian Karst revealed good statistic correlation between $\mathrm{Rb}$, Si and $\mathrm{Zr}\left(\mathrm{R}^{2}=0.7-0.9\right)$ and a markedly lower correlation between $\mathrm{Ti}$ and $\mathrm{Si}, \mathrm{Rb}, \mathrm{Zr}\left(\mathrm{R}^{2}=0.2-0.4\right.$; Fig. 9a). Aluminium measured in a few samples with an $\mathrm{Al}$ content above detection limits revealed good statistic correlations $\left(\mathrm{R}^{2}=0.8-0.9\right)$ with $\mathrm{Si}, \mathrm{Rb}$ and $\mathrm{Zr}$. High negative correlation $\left(\mathrm{R}^{2}=-0.5\right.$ to -0.8$)$ between these detrital proxies and the carbonate proxy $\mathrm{Ca}$ (Fig. 9a) reflects the effect of dilution of terrigenous siliciclastics in marine carbonates (Brumsack 2006). The concentrations of Al, Si, K, Ti, Zr and $\mathrm{Rb}$ increase and the $\mathrm{Zr} / \mathrm{Rb}$ and $\mathrm{Ti} / \mathrm{Rb}$ ratios decrease in the equivalents of the KWI in the Moravian Karst sections, along with the increasing MS values and $\mathrm{U}_{\mathrm{GRS}}$ concentrations (Fig. 7). As $\mathrm{Zr}$ and $\mathrm{Ti}$ are contained in silt- and fine-grained sand-sized heavy minerals, the $\mathrm{Zr} / \mathrm{Rb}$ and $\mathrm{Ti} / \mathrm{Rb}$ ratios can be used as proxies of detrital grain size in fine-grained siliciclastic and mixed carbonate-siliciclastic sediments (e.g. Fralick \& Kronberg 1997, Dypvik \& Harris 2001, Schulte \& Speijer 2009, Jones et al. 2012, Nováková et al. 2013). This geochemical signature suggests that carbonate production decelerated during the KWE along with the decreasing grain size of the detrital supply. On the other hand, $\mathrm{Zr} / \mathrm{Al}_{2} \mathrm{O}_{3}$ can be used as a proxy of volcanic input (Racki et al. 2002, Yudina et al. 2002, Pujol et al. 2006). Sufficiently high Al concentrations (above detection limits) were measured from the LKWI and UKWI and the basal Famennian strata, suggesting that the $\mathrm{Zr} / \mathrm{Al}_{2} \mathrm{O}_{3}$ ratio could be used for comparative purposes. The $\mathrm{Zr} / \mathrm{Al}_{2} \mathrm{O}_{3}$ values are higher than 0.001 (mean values 0.003 ) suggesting a volcanic input, as reported by Racki et al. (2002), in a geographically close section in southern Poland. In addition, a remarkable excess of Ti in the Moravian Karst Fr-Fa sections (mean Ti/Al $=0.2$ ), relative to the Post Archean Australian Shale (PAAS) standard ( Ti/Al = 0.06; Taylor \& McLennan 1985), suggests that $\mathrm{Ti}$ may be connected with $\mathrm{Ti}$ rich mafic volcanism (Dvořák 1985, Přichystal 1993, Janoušek et al. 2014).

In the Steinbruch Schmidt, there is a very good correlation $\left(\mathrm{R}^{2}=0.9\right)$ between all the measured detrital proxies (Group 1; Si, Al, Ti, K, Rb, Zr; Fig. 9a) and a very high negative correlation of the detrital proxies with $\mathrm{Ca}\left(\mathrm{R}^{2}=\right.$ $-0.9)$. The concentrations of detrital proxies increase in the shales of the KWI and in the basal Famennian strata, whilst $\mathrm{Zr} / \mathrm{Rb}, \mathrm{Zr} / \mathrm{Al}, \mathrm{Ti} / \mathrm{Rb}$ and Ti/Al decrease in the KWI. The $\mathrm{Zr} / \mathrm{Al}$ and $\mathrm{Zr} / \mathrm{Rb}$ values, which have both the same trends and high covariance $\left(R^{2}=0.7\right)$, reveal cyclic pattern in the Steinbruch Schmidt: a decrease toward the LKWI base followed by increase to the base of the linguiformis Zone and, again, a decrease toward the base of the UKWI and increase toward the Upper triangularis $(=P a$. minuta minuta) conodont $\mathrm{Zone}$. The $\mathrm{Zr} / \mathrm{Al}_{2} \mathrm{O}_{3}$ ratios suggest a possible derivation of the detrital phase from volcanic sources in the Steinbruch Schmidt (mean values 0.0018), which may be supported by the occurrence of a bentonite layer be- tween the two KWI (Schindler 1990b, 1993; Kaufmann et al. 2004).

Based on a combination of the above-mentioned geochemical signatures ( $\mathrm{Al}$ increase, $\mathrm{Zr} / \mathrm{Rb}, \mathrm{Ti} / \mathrm{Rb}$ decrease in KWI) and biostratigraphy, the Moravian Karst sections can be correlated in high-resolution manner with the Steinbruch Schmidt (Fig. 8). These correlations are consistent with GRS and MS correlations.

Good correlations of Fe vs. Si $\left(\mathrm{R}^{2}=0.8-0.9\right)$ and Fe $v s$. $\mathrm{Rb}\left(\mathrm{R}^{2}=0.7-0.8\right.$; Fig. $\left.9 \mathrm{~b}\right)$ at Hády and Šumbera suggest that most of $\mathrm{Fe}$ is associated with the clay fraction. These correlations are lower $\left(\mathrm{R}^{2}=0.3-0.4\right)$ in Steinbruch Schmidt and Lesní lom. MS and the detrital proxy curves reveal very similar stratigraphic trends (Fig. 7). Moreover, data from the Hády section show a high statistic correlation between MS vs. Rb ( $\mathrm{R}^{2}=0.8$; Fig. 9b), MS vs. $\mathrm{Si}\left(\mathrm{R}^{2}=0.8\right)$ and lower correlation between MS vs. Ti $\left(\mathrm{R}^{2}=0.4\right)$. This suggests that the MS signal from the studied sections is driven by detrital particles diluted in the diamagnetic calcium carbonate (see Riquier et al. 2009 for comprehensive MS analysis of the Steinbruch Schmidt section).

Group 2 from the PCA comprises of elements $\mathrm{Pb}, \mathrm{Cu}$ and $\mathrm{Zn}$ in Steinbruch Schmidt (Fig. 9a) and $\mathrm{Pb}$ and $\mathrm{Cu}$ in the Moravian Karst sections, which are often used as palaeoproductivity and redox potential proxies (e.g. Schnetger et al. 2000, Dean 2007, Śliwiński et al. 2010). In all Moravian sections, $\mathrm{Cu}, \mathrm{Pb}$ and partly $\mathrm{Zn}$ show poor correlation with the other elements. $\mathrm{Zn}$ correlates well with $\mathrm{Rb}$ in the basal Famennian strata at Šumbera and Hády sections $\left(\mathrm{R}^{2}=0.7\right)$, reflecting its association with clays (Schlegel et al. 2001, Sdiri et al. 2014). In the Lesní lom section, high values of $\mathrm{Pb}$ were found in the UKWI and correlate partly with high Rb (Fig. 7). Lead weakly correlates with $\mathrm{Fe}\left(\mathrm{R}^{2}=0.3\right)$ at Lesní lom, which may indicate its incorporation in pyrite. Nevertheless, higher contents of $\mathrm{Pb}$ may also be attributed to microbialites (Kamber et al. 2004).

Zinc and lead show good statistic correlation $\left(\mathrm{R}^{2}=0.8\right)$ in the Steinbruch Schmidt, whereas correlation between $\mathrm{Cu} / \mathrm{Zn}$ and $\mathrm{Pb} / \mathrm{Cu}$ is poor $\left(\mathrm{R}^{2}=0.1-0.2\right)$. Aluminium and $\mathrm{Rb}$ moderately correlate with $\mathrm{Cu}\left(\mathrm{R}^{2}=0.6\right)$ but weakly with $\mathrm{Pb}$ and $\mathrm{Zn}\left(\mathrm{R}^{2}=0.2\right)$. Zinc and $\mathrm{Cu}$ reveal very low correlation with $\mathrm{Fe}\left(\mathrm{R}^{2}=0.2-0.3\right)$. These correlations may indicate that a significant portion of $\mathrm{Cu}$ is incorporated in clay minerals and $\mathrm{Pb}$ and $\mathrm{Zn}$ probably in organic matter. Zinc and $\mathrm{Cu}$ are partially related to pyrite. Concentrations of non-normalised palaeoproductivity proxies $\mathrm{Pb}$ (Fig. 8), $\mathrm{Zn}$ and $\mathrm{Cu}$, as well as $\mathrm{Pb} / \mathrm{Rb}, \mathrm{Zn} / \mathrm{Rb}$ and $\mathrm{Cu} / \mathrm{Rb}$ increase in the LKWI and more distinctively at the top of the UKWI.

Ratios of $\mathrm{Mn} / \mathrm{Al}$ and $\mathrm{Fe} / \mathrm{Al}$ are often regarded as proxies of hydrothermal input (Taylor \& McLennan 1985) or anoxic conditions (Maynard 2005, Lyons \& Severmann 2006). In the Moravian Karst, anomalously high Mn/Al ratios (mean 0.146; compare to PAAS: $\mathrm{Mn} / \mathrm{Al}=0.0085$ ) 
may indicate a general hydrothermal influence connected with widespread bimodal magmatism (Přichystal 1993, Janoušek et al. 2014). Manganese does not correlate with Fe, while higher Fe/Al (mean value 0.9) may reflect anoxic conditions (Lyons \& Severmann 2006) or could be also linked to volcanic activity.

Uranium measured by ICP-MS (and calculated U/Th) shows higher values compared to $\mathrm{U}_{\mathrm{GRS}}$ in both the KWE black shale intervals from Steinbruch Schmidt (Fig. 7). Lower values of $\mathrm{U} / \mathrm{Th}_{\mathrm{GRS}}$ are caused by the averaging of $\mathrm{U}$ and Th content in a larger bulk of scanned rock, which included surrounding limestones.

\section{Discussion}

The conodont biostratigraphic data from the Moravian sections document the overall biostratigraphic span of the Lower or Upper rhenana to Palmatolepis minuta minuta or younger conodont zones and enable to us follow the biotic and facies changes at the Fr-Fa boundary in detail. Multilocular foraminifers of the Eogeinitzina, EonodosariaNanicella association reach the UKWI and disappear at or below the Fr-Fa boundary. The Moravian facies are represented by ramp limestones (see Hladil et al. 1991). The metazoan reef environment was considerably reduced during the late Frasnian (Schindler 1990b, McGhee 1996, Copper 2002). Heavily calcifying biota was largely replaced by calcimicrobial consortia, such as Renalcis, Rothpletzella, Girvanella and Epiphyton, which dominated in the uppermost Frasnian and Famennian (Copper 2002). Microbial facies reflecting this environmental change were recorded from various shallow-water settings across the world (e.g. Wood 2000, Whalen et al. 2002, Chow \& George 2004, Shen et al. 2008, Rakociński \& Racki 2016) although the traces of microbial activity were also recorded in deep-water environments ( $e$ g. in the Holy Cross Mountains; Marynowski et al. 2011). Microbial structures represented by renalcids and Rothpletzella from the Šumbera area were previously depicted by Racki et al. (2002). The currently recorded Moravian association of calcimicrobes is more diversified than that found in the Holy Cross Mts. in Poland (Rakociński \& Racki 2016) and might be compared with calcimicrobe associations from reef environments at various sites, including the Australian Canning Basin (e.g. Wood 2000, 2004), China (Shen et al. 2010) or Russia (Antoshkina 2006). However, the Moravian Karst ramp environment was less favourable for the development of larger mud mounds than those reported from Australia (e.g. Wood 2000, 2004) or China (Shen et al. 2010). Nevertheless, the wide occurrence of microbial limestones and calcimicrobes in the Moravian Karst follows the global trends during the uppermost Frasnian and lower Famennian.
Before starting a discussion of geochemical and petrophysical signatures it is important to highlight that the limestones in Moravia are very pure and were deposited in an area, to a certain extent similarly as in the neighbouring southern Poland, under the influence of strong bimodal magmatism (Přichystal 1993, Racki et al. 2002, Kalvoda et al. 2008, Janoušek et al. 2014) and that their detrital input may have been largely controlled by atmospheric volcanic transport.

Carbonate successions of the Moravian Karst display an increase in detrital proxies (Al, K, Si, Rb, Zr and Ti contents), GRS measured U concentrations, U/Th ratios and MS values in the uppermost Frasnian (Upper rhenana to linguiformis conodont zones) strata. In contrast the $\mathrm{Zr} / \mathrm{Rb}$, $\mathrm{Ti} / \mathrm{Rb}$ ratios and $\mathrm{CaO}$ content decrease (Figs 7, 8). These geochemical trends correlate with the Kellwasser intervals in the reference section of Steinbruch Schmidt, where high detrital concentrations are present in the shaly beds and low concentrations in limestones of KWE; whereas $\mathrm{Zr} / \mathrm{Rb}$ and $\mathrm{Ti} / \mathrm{Rb}$ values are low and U/Th values are high both in shaly and carbonate facies of KWE (Figs 7, 8). A decrease in $\mathrm{Ti} / \mathrm{Rb}$ and $\mathrm{Zr} / \mathrm{Rb}$ in the KWE level in the Moravian Karst and Steinbruch Schmidt section is in accordance with data from the Harz Mountains and in the LKE level from the Eifel Mountains in Germany (Pujol et al. 2006, Riquier et al. 2006). Contrary to Dopieralska et al. (2016) who based on $\mathrm{Nd}$ isotopes (among others also in Steinbruch Schmidt section) postulated a fall in sea level during the deposition of the Kellwasser intervals, the decrease in Ti/Al was interpreted here as the result of restricted clastic input during sea-level rise (Pujol et al. 2006, Riquier et al. 2006). The decrease in grain size of the siliciclastic supply and carbonate productivity in the KWE intervals is as a consequence of a deepening and is in accord with our geochemical signature from the Moravian Karst and the Steinbruch Schmidt sections. The minima in $\mathrm{Zr} / \mathrm{Rb}$ at the base of the LKWI and UKWI in Steinbruch Schmidt coincide with the maximum flooding surfaces reported by Devleeschouwer et al. (2002). The $\mathrm{Zr} / \mathrm{Rb}$ increase is related to progradational microfacies parasequences (Devleeschouwer et al. 2002) of highstand system tract (LKWI) and lowstand system tract (above LKWI in the Upper rhenana conodont Zone), together with lower parts of a transgressive system tract (top of the Upper rhenana conodont Zone). Values of $\mathrm{Zr} / \mathrm{Rb}$ decrease in the upper part of the transgressive system tract (linguiformis conodont Zone) and reaches a minimum at the maximum flooding surface at the base of UKWI. $\mathrm{Zr} / \mathrm{Rb}$ values increase again during the highstand system tract of the UKWI.

On the other hand, an increase in $\mathrm{Zr} / \mathrm{Al}_{2} \mathrm{O}_{3}$ was reported from the KWI of the Holy Cross Mountains, Poland, from the Montagne Noire, France and the Polar Urals, Russia (Racki et al. 2002, Yudina et al. 2002, Pujol et al. 2006). The increase in $\mathrm{Zr} / \mathrm{Al}_{2} \mathrm{O}_{3}(>0.001)$ can be explained by 
a coarser clastic, often volcaniclastic contribution (Racki et al. 2002, Pujol et al. 2006, Racki et al. 2012). Racki et al. (2002) also reported a $\mathrm{Zr} / \mathrm{Al}_{2} \mathrm{O}_{3}$ increase at the base of the Famennian from probably another Šumbera section, which can be equivalent to a $\mathrm{Zr} / \mathrm{Rb}$ peak in the Lower triangularis (= Pa. subperlobata) conodont Zone from our dataset (Fig. 7). However, this interval was not documented from the base of Famennian at Hády. The excessive Zr, showing good correlation with $\mathrm{Rb}$ and $\mathrm{Si}$ and excessive $\mathrm{Ti}$ in the Moravian Karst, together with similar data from southern Poland, may represent a reflection of the widespread coeval bimodal magmatism of the Moravian-Silesian Zone (Dvořák 1985, Přichystal 1993, Janoušek et al. 2014). It may also be in accord with anomalously high $\mathrm{Mn} / \mathrm{Al}$, which is a proxy of hydrothermal input. A good statistical correlation exists between $\mathrm{Si}, \mathrm{Rb}$ and $\mathrm{Zr}$ in the Moravian Karst sections, which may be in accordance with the common presence of zircon of volcanic origin in the Frasnian sediments from Moravia (Hladil 2002, Gilíková et al. 2006, Krmíček 2006). Volcaniclastic ilmenite, epidote, zircon and rutile were reported in Devonian tuffites, which were found in close vicinity of the studied sections (Gilíková et al. 2006, Krmíček 2006). However, Al (or $\mathrm{Al}_{2} \mathrm{O}_{3}$ ) normalization could be biased due to very low $\mathrm{Al}$ concentrations, which can result in artificially higher ratios (Van der Weijden 2002, Tribovillard et al. 2006, Collin et al. 2015). This could also play a role in the case of the Moravian sections.

In all Moravian sections, $\mathrm{Cu}, \mathrm{Pb}$ and, to some extent, $\mathrm{Zn}$ show poor correlation with the other elements and are probably mostly bound to organic matter. The absence of mutual correlation among palaeoproductivity proxies in all sections probably reflects their relative affinities to different types of organic matter.

The KWI in the Moravian Karst and Steinbruch Schmidt are characterized by increased U and U/Th. Seawater $U$ is taken up by sediments under suboxic to anoxic conditions (Zheng et al. 2002, Morford et al. 2009), resulting in enrichment relative to Th (Wignall \& Myers 1988). However, $\mathrm{U}$ is mobile during diagenesis and/or can be tied to detrital minerals (Calvert \& Pedersen 1993, Jones \& Manning 1994). In pure limestones of the Moravian sections the $U$ content is significantly higher compared with that of the black shales of LKWI and UKWI in Steinbruch Schmidt (Tab. 2; Fig. 7). Higher Th concentrations are characteristic of clastic sediments (or clastic-rich carbonate sediments) rather than for "pure" carbonates; thus the $\mathrm{U} / \mathrm{Th}$ ratio can therefore be higher in carbonate sediments (Bond et al. 2004). However, high U/Th values from the Moravian Karst Fr-Fa sections (Fig. 7) are uncommon in sedimentary limestones deposited in oxygenated environments ranging from shallow epeiric seas to deep open oceans (Plank \& Langmuir 1998, Ruffell \& Worden 2000, Hladil et al. 2006, Bond et al. 2013). Hladil et al. (2006) noticed a similar anomalously high content of $\mathrm{U}$, displayed by very low $\mathrm{Th} / \mathrm{U}$ signatures, in the Eifelian and Frasnian shallow water "pure" limestones of the Moravian Karst. They excluded the effect of anoxic waters on the U enrichment due to low total organic carbon (TOC) concentrations and low U: TOC covariance; furthermore they reported similar U-rich carbonates from the NE margin of the Great Bahama Bank, where U is related to impurities from Saharan dust. Variations in U concentration correlate well with XRF siliciclastic content in the Lesní lom and Hády sections (Fig. 7). This could indicate that a potential source of $\mathrm{U}$ enrichment is the detritic fraction, possibly derived from the widespread Devonian felsic volcanites (Gilíková et al. 2006, Krmíček 2006). However, higher U enrichment may also reflect the bias of normalisation in pure limestones. Increased $\mathrm{U}$ and decreased $\mathrm{Th} / \mathrm{U}$ were reported previously from other Moravian Karst Fr-Fa sections (Ostrov u Macochy, Mokrá; Bábek et al. 2007) and from the Hranice Palaeozoic (Czech Republic; Hladil et al. 2006). The U maxima of LKWI and UKWI from Lesní lom and Hády (Fig. 8) can be correlated with maxima of the lower and upper part of the $6^{\text {th }}$ cycle of Hladil et al. (2006, p. 234). High U/Th values from the KWI were also reported in earlier studies from Montagne Noire and Morocco (Riquier et al. 2005, 2009) and low Th/U values from the Holy Cross Mountains, Poland (Bond \& Zatoń 2003, Bond et al. 2004) and Alberta, Canada (Bond et al. 2013). This is in accordance with interpretation of hypoxic to anoxic conditions associated with both KWE maximum flooding surfaces (Devleeschouwer et al. 2002), based on the high TOC content and excessive concentrations of siderophile and chalcophile elements (Racki et al. 2002, Tribovillard et al. 2004, Riquier et al. 2005, Pujol et al. 2006). Geochemical and sedimentological proxies indicate a widespread hypoxia to anoxia typical of most sections exhibiting the Kellwasser Crisis (Joachimski \& Buggisch 1993, Racki 2005, Gereke \& Schindler 2012, George et al. 2014); however, exceptions do occur (Carnic Alps, Austria; Bond et al. 2004). Gereke (2007) discussed the possibility that even local oxic "events" may be involved in the course of the Kellwasser Crisis.

\section{Conclusions}

The detailed conodont zonation in the Moravian sections made it possible to follow, in detail, biotic changes across the Fr-Fa boundary. The ramp limestones recorded the decline of metazoan biota, largely replaced by rich calcimicrobial associations, thus consistent with the global trend during this interval. The association of multilocular foraminifers reached the UKWI and became extinct in the uppermost Frasnian close to the Fr-Fa boundary. The Kellwasser Crisis left comprehensible petrophysical and 
geochemical signatures in the studied Fr-Fa sections from the Moravian Karst. These were probably related to a decrease in carbonate productivity, which caused a relative increase in siliciclastic components in the sediments $(\mathrm{Si}$, $\mathrm{Rb}$, Ti and $\mathrm{Zr}$; Fig. 7). Lower $\mathrm{Zr} / \mathrm{Rb}$ and $\mathrm{Ti} / \mathrm{Rb}$ ratios (Fig. 8) indicate a decrease in grain size, related to the increase in distance from a clastic source, or attenuation of aeolian transport. Similar changes were documented from the reference section Steinbruch Schmidt, related to maximum flooding surfaces and high stand system tracts (Devleeschouwer et al. 2002) of both KWI (Fig. 8). Element normalizations in the Moravian Karst sections may be somewhat biased due to the pure limestones. However, significant $\mathrm{Zr}, \mathrm{TiO}_{2}, \mathrm{Mn}$ or $\mathrm{Fe}_{2} \mathrm{O}_{3}$ enrichments may indicate some influence of volcanic sources at the studied Moravian Karst Fr-Fa sections, which is in accordance with previous results from the Moravian Karst (Zukalová 1980, Dvořák 1985, Hladil 2002, Racki et al. 2002) and southern Poland (Racki et al. 2002, Pujol et al. 2006, Rakociński et al. 2016). MS values display a close link with siliciclastic content (Fig. 7) and are therefore considered as proxy of siliciclastic influx across Fr-Fa boundary interval in the Moravian Karst sections. U/Th increase in the LKWI and UKWI of the Steinbruch Schmidt section (Fig. 7) supports previously interpreted dysoxic to anoxic conditions (e.g. Pujol et al. 2006) during the deposition in the event intervals. U concentrations are also generaly high in the studied Moravian Karst sections. Higher U content is probably related to a detritic fraction rich in $\mathrm{U}$ (good correlation with siliciclastic content proxies). Enrichment in palaeoproductivity proxies $(\mathrm{Zn}, \mathrm{Pb})$ appears only in the LKWI and UKWI of the Steinbruch Schmidt section, whereas only relative increases in $\mathrm{Zn}$ and $\mathrm{Pb}$ were documented in the (Upper?) Kellwasser interval from the Lesní lom and Šumbera sections.

\section{Acknowledgements}

The reviewers Marek Narkiewicz and Michał Rakociński are thanked for their helpful suggestions. This research was supported by the Czech Science Foundation project GA14-18183S and is a contribution to the International Geoscience Programme (IGCP) Project 652 - Reading geologic time in Paleozoic sedimentary rocks.

\section{References}

Adachi, N., EzaKi, Y. \& LiU, J. 2004. The fabrics and origin of peloids immediately after the end-Permian extinction, Guizhou Province, South China. Sedimentary Geology 164, 161-178. DOI 10.1016/j.sedgeo.2003.10.007

Alekseev, A.S., Kononova, L.I. \& Nikishin, A.M. 1996. The Devonian and Carboniferous of the Moscow Syneclise (Russian
Platform): stratigraphy and sea-level changes. Tectonophysics 268, 149-168. DOI 10.1016/S0040-1951(96)00229-6

Algeo, T.J. \& Scheckler, S.E. 1998. Terrestrial-marine teleconnections in the Devonian: links between the evolution of land plants, weathering processes, and marine anoxic events. Philosophical Transactions of the Royal Society of London B 353, 113-130. DOI 10.1098/rstb.1998.0195

Algeo, T.J., Berner, R.A., Maynard, J.B. \& Scheckler, S.E. 1995. Late Devonian oceanic anoxic events and biotic crises: 'Rooted' in the evolution of vascular land plants? GSA Today 5, 64-66.

AntoshkinA, A.I. 2006. Palaeoenvironmental implications of Palaeomicrocodium in Upper Devonian microbial mounds of the Chernyshev Swell, Timan-northern Ural Region. Facies 52, 611-625. DOI 10.1007/s10347-006-0083-z

Bábek, O., Kalvoda, J., Aretz, M., Cossey, P.J., Devuyst, F.X., Herbig, H.G. \& Sevastopulo, G. 2010. The correlation potential of magnetic susceptibility and outcrop gamma-ray logs at Tournaisian-Viséan boundary sections in western Europe. Geologica Belgica 13, 291-307.

Bábek, O., Kalvoda, J., Cossey, P., Šimíček, D., Devuyst, F.X. \& Hargreaves, S. 2013. Facies and petrophysical signature of the Tournaisian/Viséan (Lower Carboniferous) sea-level cycle in carbonate ramp to basinal settings of the Wales-Brabant massif, British Isles. Sedimentary Geology 284-285, 197-213. DOI 10.1016/j.sedgeo.2012.12.008

BÁBeK, O., Kumpan, T., Kalvoda, J. \& Matys Grygar, T. 2016. Devonian/Carboniferous boundary glacioeustatic fluctuations in a platform-to-basin direction: A geochemical approach of sequence stratigraphy in pelagic settings. Sedimentary Geology 337, 81-99. DOI 10.1016/j.sedgeo.2016.03.009

BÁBeK, O., P̌̌ikryl, T. \& HLAdil, J. 2007. Progressive drowning of carbonate platform in the Moravo-Silesian Basin (Czech Republic) before the Frasnian/Famennian event: facies, compositional variations and gamma ray spectrometry. Facies 53(2), 293-316. DOI 10.1007/s10347-006-0095-8

Bond, D.P.G. \& Wignall, P. 2008. The role of sea-level change and marine anoxia in the Frasnian-Famennian (Late Devonian) mass extinction. Palaeogeography, Palaeoclimatology, Palaeoecology 263, 107-118. DOI 10.1016/j.palaeo.2008.02.015

Bond, D. \& ZATON, M. 2003. Gamma-ray spectrometry across the Upper Devonian basin succession at Kowala in the Holy Cross Mountains (Poland). Acta Geologica Polonica 53, 93-99.

Bond, D., Wignall, P.B. \& RACKi, G. 2004. Extent and duration of marine anoxia during the Frasnian-Famennian (Late Devonian) mass extinction in Poland, Germany, Austria and France. Geological Magazine 141(2), 173-193. DOI 10.1017/S0016756804008866

Bond, D.P.G., Zatoń, M., Wignall, P.B. \& Marynowski, L. 2013. Evidence for shallow water 'Upper Kellwasser' anoxia in the Frasnian-Famennian reefs of Alberta, Canada. Lethaia 46, 355-368. DOI 10.1111/let.12014

Bratton, J.F., Berry, W.B.N. \& Morrow, J.R. 1999. Anoxia predates Frasnian-Famennian boundary mass extinction horizont in the Great Basin, USA. Palaeogeography, Palaeoclimatology, Palaeoecology 154, 275-292.

DOI 10.1016/S0031-0182(99)00116-9

Brett, C.E., Mclaughlin, P.I., Schindler, E., Histon, K. \& 
Ferretti, A. 2012. Time specific aspects of facies: State of the art, examples, and possible causes. Palaeogeography, Palaeocliamtology, Palaeoecology 367-368, 6-18.

DOI 10.1016/j.palaeo.2012.10.009

BRUMSACK, H.J. 2006. The trace metal content of recent organic carbon-rich sediments: Implications for Cretaceous black shale formation. Palaeogeography, Palaeoclimatology, Palaeoecology 232, 344-361.

DOI 10.1016/j.palaeo.2005.05.011

Buggisch, W. 1972. Zur Geologie und Geochemie der Kellwasserkalke und ihrer begleitenden Sedimente (Unteres Oberdevon). Abhandlungen des Hessischen Landesamtes für Bodenforschung 62, 1-68.

Calvert, S.E. \& Pedersen, T.F. 1993. Geochemistry of recent oxic and anoxic marine sediments - implications for the geological record. Marine Geology 113, 67-88. DOI 10.1016/0025-3227(93)90150-T

CAsier, J.G. \& LethiERs, F. 1998. Ostracods late Devonian mass extinction; the Schmidt Quarry parastratotype (Kellerwald, Germany). Comptes Rendus de l'Académie des Sciences/Earth and Planetary Science 326, 71-78.

Chen, D. \& Tucker, M.E. 2004. Palaeokarst and its implication for the extinction event at the Frasnian-Famennian boundary (Guilin, south China). Journal of the Geological Society, London 161, 895-898. DOI 10.1144/0016-764904-035

Chen, D., Qing, H. \& Li, R. 2005. The Late Devonian Frasnian-Famennian (F/F) biotic crisis: insights from $\delta^{13} \mathrm{C}_{\text {carb}}, \delta^{13} \mathrm{C}_{\text {org }}$ and ${ }^{87} \mathrm{Sr} /{ }^{86} \mathrm{Sr}$ isotopic systems. Earth and Planetary Science Letters 235, 151-166.

DOI 10.1016/j.epsl.2005.03.018

Chow, N. \& George, A.D. 2004. Tepee-shaped agglutinated microbialites: an example from a Famennian carbonate platform on the Lennard Shelf, northern Canning Basin, Western Australia. Sedimentology 51, 253-265. DOI 10.1046/j.1365-3091.2003.00620.x

Collin, P.Y., Kershaw, S., Tribovillard, N., Forel, M.B. \& Crasquin, S. 2015. Geochemistry of post-extinction microbialites as a powerful tool to assess the oxygenation of shallow marine water in the immediate aftermath of the end-Permian mass extinction. International Journal of Earth Sciences 104, 1025-1037. DOI 10.1007/s00531-014-1125-3

Copper, P. 2002. Reef development at the Frasnian-Famennian mass extinction boundary. Palaeogeography, Palaeoclimatology, Palaeoecology 181, 27-66.

DOI 10.1016/S0031-0182(01)00472-2

Crick, R.E., Ellwood, B.B., Feist, R., El Hassani, A., Schindler, E., Dreesen, R., Over, D.J. \& Girard, C. 2002. Magnetostratigraphy susceptibility of the Frasnian/Famennian boundary. Palaeogeography, Palaeoclimatology, Palaeoecology 181, 67-90. DOI 10.1016/S0031-0182(01)00473-4

Da Silva, A.C., De Vleeschouwer, D., Boulvain, F., Claeys, P., Fagel, N., Humblet, M., Mabille, C., Michel, J., Sardar Abadi, M., PAs, D. \& DekKers, M.J. 2013. Magnetic susceptibility as a high-resolution correlation tool and as a climatic proxy in Paleozoic rocks - Merits and pitfalls: Examples from the Devonian in Belgium. Marine and Petroleum Geology 46, 173-189. DOI 10.1016/j.marpetgeo.2013.06.012

Da Silva, A.C., Mabille, C. \& Boulvain, F. 2009. Influence of sedimentary setting on the use of magnetic susceptibility: ex- amples from the Devonian of Belgium. Sedimentology 56, 1292-1306. DOI 10.1111/j.1365-3091.2008.01034.x

DEAN, W.E. 2007. Sediment geochemical records of productivity and oxygen depletion along the margin of western North America during the past 60,000 years: teleconnections with Greenland Ice and the Cariaco Basin. Quaternary Science Reviews 26, 98-114. DOI 10.1016/j.quascirev.2006.08.006

De Vleeschouwer, D., Cricifix, M., Bounceur, N. \& Claeys, P. 2014. The impact of astronomical forcing on the Late Devonian greenhouse climate. Global and Planetary Change 120, 65-80. DOI 10.1016/j.gloplacha.2014.06.002

Devleeschouwer, X., Herbosch, A. \& Préat, A. 2002. Microfacies, sequence stratigraphy and clay mineralogy of a condensed deep-water section around the Frasnian/Famennian boundary (Steinbruch Schmidt, Germany). Palaeogeography, Palaeoclimatology, Palaeoecology 181, 171-193.

DOI 10.1016/S0031-0182(01)00478-3

DevleEschouwer, X., Riquier, L., BÁbek, O., De Vleeshouwer, D., Petitclerc, E., Sterckx, S. \& Spassov, S. 2015. Magnetization carriers of grey to red deep-water limestones in the GSSP of the Givetian-Frasnian boundary (Puech de la Suque, France): signals influenced by moderate diagenetic overprinting, 245-256. In Da Silva, A.C., Whalen, M.T., Hladil, J., Chadimová, L., Chen, D., Spassov, S., Boulvain, F. \& Devleeschouwer, X. (eds) Magnetic Susceptibility Application: A Window onto Ancient Environments and Climatic Variations. Geological Society of London, Special Publications 414. DOI 10.1144/SP414.15

Dopieralska, J., Belka, Z. \& Walczak, A. 2016. Nd isotope composition of conodonts: An accurate proxy of sea-level fluctuations. Gondwana Research 34, 284-295.

DOI 10.1016/j.gr.2015.02.022

Doveton, J.H. \& MerRiam, D.F. 2004. Borehole petrophysical chemostratigraphy of Pennsylvanian black shales in the Kansas subsurface. Chemical Geology 206, 249-258. DOI 10.1016/j.chemgeo.2003.12.027

DvořÁK, J. 1985. Tektogeneze devonu a spodního karbonu Hornoslezské pánve. Zemní plyn a Nafta 30(1), 1-14.

DYPVIK, H. \& HARRIS, N.B. 2001. Geochemical facies analysis of fine-grained siliciclastics using $\mathrm{Th} / \mathrm{U}, \mathrm{Zr} / \mathrm{Rb}$ and $(\mathrm{Zr}+\mathrm{Rb} / \mathrm{Sr})$ ratios. Chemical Geology 181, 131-146. DOI 10.1016/S0009-2541(01)00278-9

Ellwood, B.B., Crick, R.E., El Hassani, A., Benoist, S.L. \& YounG, R.H. 2000. Magnetosusceptibility event and cyclostratigraphy method applied to marine rocks: detrital input versus carbonate productivity. Geology 28, 1135-1138. DOI 10.1130/0091-7613(2000)28<1135:MEACMA >2.0.CO;2

FEIST, R. 1985. Devonian stratigraphy of the South-eastern Montagne Noire (France). Courier Forschungsinstitut Senckenberg 75, 331-352.

Feist, R. \& SchindLER, E. 1994. Trilobites during the Frasnian Kellwasser Cisis in European Late Devonian cephalopod limestones. Courier Forschungsinstitut Senckenberg 169, 195-223.

Fralick, P.W. \& KronberG, B.I. 1997. Geochemical discrimination of clastic sedimentary rock sources. Sedimentary Geology 113, 111-124. DOI 10.1016/S0037-0738(97)00049-3

Franke, W. 1995. III.A Introduction, 29-30. In Dallmeyer, R.D., Franke, W. \& Weber, K. (eds) Pre-Permian Geology of 
Central and Eastern Europe. Springer, Berlin, Heidelberg, New York.

FRANKE, W. 2002. The mid-European segment of the Variscides: tectonostratigraphic units, terrane boundaries and plate tectonic evolution, 35-61. In Winchester, J.A., Pharaoh, T.C. \& Verniers, J. (eds) Palaeozoic amalgamation of Central Europe. Geological Society of London, Special Publications 201.

George, A.D., Chow, N. \& Trinajstic, K.M. 2014. Oxic facies and the Late Devonian mass extinction, Canning Basin, Australia. Geology 42, 327-330. DOI 10.1130/G35249.1

GEREKE, M. 2007. Die oberdevonische Kellwasser-Krise in der Beckenfazies von Rhenoherzynikum und Saxothuringikum (spätes Frasnium/frühestes Famennium, Deutschland). Kölner Forum für Geologie und Paläontologie 17, 1-228.

Gereke, M. \& Schindler, E. 2012. "Time-Specific Facies" and biological crises - The Kellwasser Event interval near the Frasnian/Famennian boundary (Late Devonian). Palaeogeography, Palaeoclimatology, Palaeoecology 367-368, 19-29. DOI 10.1016/j.palaeo.2011.11.024

Gereke, M., Luppold, F.W., Piecha, M., Schindler, E. \& STOPPEL, D. 2014. Die Typlokalität der Kellwasser-Horizonte im Oberharz, Deutschland. Zeitschrift der Deutschen Gesellschaft für Geowissenschaften, 165(2), 145-162.

DOI 10.1127/1860-1804/2014/0066

Gilíková, H., Leichmann, J. \& BuRiáneK, D. 2006. Record of sialic volcanism found in the Devonian clastic sediments at the eastern margin of the Bohemian Massif. Geologické Výzkumy na Moravě a ve Slezsku v roce 2005, 72-74.

GIRARD, C. 1995. Les biofaciès à conodontes à la limite Frasnien/Famennien en Montagne Noire (France). Implications stratigraphiques. Comptes Rendus de l'Académie des Sciences/Series II a 321, 689-692.

GirARD, C. \& FeIST, R. 1997. Eustatic trends in conodont diversity across the Frasnian-Famennian boundary in the stratotype area, Montagne Noire, Southern France. Lethaia 29, 329-337. DOI 10.1111/j.1502-3931.1996.tb01668.x

Grimm, M.C. 1998. Systematik und Paläoökologie der Buchiolinae nov. subfam. Schweizerische Paläontologische Abhandlungen 118, 1-176.

Groos-Uffenorde, H. \& Schindler, E. 1990. The effect of global events on entomozoacean ostracods, 101-112. In Whatley, R. \& Maybury, C. (eds) Ostracoda and Global Events. British Micropalaeontological Society Publication Series. Springer Chapman \& Hall, London.

Halgedahl, S.L., Jarrard, R.D., Brett, C.E. \& Allison, P.A. 2009. Geophysical and geological signatures of relative sea level change in the upper Wheeler Formation, Drum Mountains, West-Central Utah: A perspective into exceptional preservation of fossils. Palaeogeography, Palaeoclimatology, Palaeoecology 277(1-2), 34-56.

DOI 10.1016/j.palaeo.2009.02.011

Hallam, A. \& Wignall, P.B. 1997. Mass Extinctions and Their Aftermath. 325 pp. Oxford University Press, Oxford.

Hips, K. \& HaAs, J. 2006. Calcimicrobial stromatolites at the Permian-Triassic boundary in a western Tethyan section, Bükk Mountains, Hungary. Sedimentary Geology 185, 239-253. DOI 10.1016/j.sedgeo.2005.12.016

HLADIL, J. 2002. Geophysical records of dispersed weathering products on the Frasnian carbonate platform and early Famennian ramps in Moravia, Czech Republic: proxies for eustasy and palaeoclimate. Palaeogeography, Palaeoclimatology, Palaeoecology 181, 213-250.

DOI 10.1016/S0031-0182(01)00480-1

Hladil, J., \& Kalvoda, J. 1993a. Devonian boundary intervals of Bohemia and Moravia especially the Eifelian/Givetian and Frasnian/Famenian events with respect to the Silurian/Devonian and Devonian/Carboniferous boundaries, 29-50. In Narkiewicz, M. (ed.) Global boundary events. Excursion guidebook, Warszawa.

HLADIL, J. \& KalvodA, J. 1993b. Extinction and recovery successions on the Devonian marine shoals: the Eifelian-Givetian and Frasnian-Famennian events in Moravia and Bohemia. Věstník Českého geologického ústavu 68(4), 13-23.

Hladil, J., Gersl, M., Strnad, L., Frana, J., Langrova, A. \& SPISIAK, J. 2006. Stratigraphic variation of complex impurities in platform limestones and possible significance of atmospheric dust: a study with emphasis on gamma-ray spectrometry and magnetic susceptibility outcrop logging (Eifelian-Frasnian, Moravia, Czech Republic). International Journal of Earth Sciences 95(4), 703-723.

DOI 10.1007/s00531-005-0052-8

Hladil, J., Krejci, Z., Kalvoda, J., Ginter, M., Galle, A. \& BerouseK, P. 1991. Carbonate ramp environment of Kellwasser time-interval; Lesni lom, Moravia, Czechoslovakia. Bulletin de la Société Belge de Géologie 100(1-2), 57-119.

House, M.R. 2002. Strength, timing, setting and cause of midPalaeozoic extinctions. Palaeogeography, Palaeoclimatology, Palaeoecology 181, 5-25.

DOI 10.1016/S0031-0182(01)00471-0

Huang, C. \& Gong, Y. 2016. Timing and patterns of the Frasnian-Famennian event: Evidences from high-resolution conodont biostratigraphy and event stratigraphy at the Yangdi section, Guangxi, South China. Palaeogeography, Palaeoclimatology, Palaeoecology 448, 317-338.

DOI 10.1016/j.palaeo.2015.10.031

Janoušek, V., Aichler, J., Hanžl, P., Gerdes, A., Erban, V., Žáček, V., Pecina, V., Pudilová, M., HrdličKová, K., Mixa, P. \& ŽÁčKovÁ, E. 2014. Constraining genesis and geotectonic setting of metavolcanic complexes: a multidisciplinary study of the Devonian Vrbno Group (Hrubý Jeseník Mts., Czech Republic). International Journal of Earth Sciences 103, 455-483.

DOI 10.1007/s00531-013-0975-4

JoAChimski, M.M. \& Buggisch, W. 1993. Anoxic events in the late Frasnian - Causes of the Frasnian-Famennian faunal crisis? Geology 21, 675-678.

DOI 10.1130/0091-7613(1993)021<0675:AEITLF > 2.3.CO;2

JoACHIMSKi, M.M. \& BugGisch, W. 2002. Conodont apatite $\delta^{18} \mathrm{O}$ signatures indicate climatic cooling as a trigger of the Late Devonian mass extinctions. Geology 30, 711-714.

DOI 10.1130/0091-7613(2002)030<0711:CAOSIC >2.0.CO;2

Joachimski, M.M., Ostertag-Henning, C., Pancost, R.D., Strauss, H., Freeman, K.H., LittKe, R., Sinninghe Damsté, J.S. \& RACKI, G. 2001. Water column anoxia, enhanced productivity and concomitant changes in $\delta^{13} \mathrm{C}$ and $\delta^{34} \mathrm{~S}$ across the Frasnian-Famennian boundary (Kowala - Holy Cross Moun- 
tains/Poland). Chemical Geology 175, 109-131. DOI 10.1016/S0009-2541(00)00365-X

Joachimski, M.M., Pancost, R.D., Freeman, K.H., OstertaGHenning, C. \& Buggisch, W. 2002: Carbon isotope geochemistry of the Frasnian-Famennian transition. Palaeogeography, Palaeoclimatology, Palaeoecology 181, 91-109. DOI 10.1016/S0031-0182(01)00474-6

JoNEs, B. \& MANNING, D.A.C. 1994. Comparison of geochemical indices used for the interpretation of paleoredox conditions in ancient mudstone. Chemical Geology 111, 111-129. DOI 10.1016/0009-2541(94)90085-X

Jones, A.F., Macklin, M.G. \& Brewer, P.A. 2012. A geochemical record of flooding on the upper River Severn, UK, during the last 3750 years. Geomorphology 179, 89-105. DOI 10.1016/j.geomorph.2012.08.003

KalvodA, J. 1998. The main phases of extension in the eastern part of the Rhenohercynian zone. Acta Universitatis Carolinae, Geologica 42(2), 274-275.

Kalvoda, J. 2002. Late Devonian-Early Carboniferous foraminiferal fauna: zonation, evolutionary events, paleobiogeography and tectonic implications. Folia 39, 1-213.

Kalvoda, J., Bábek, O., Fatka, O., Leichmann, J., Melichar, R. \& S̆PAČEK, P. 2008. Brunovistulian terrane (Bohemian Massif, Central Europe) from late Proterozoic to late Paleozoic: a review. International Journal of Earth Sciences 97, 497-517. DOI 10.1007/s00531-007-0183-1

Kamber, B.S., Bulhar, R. \& WebB, G.E. 2004. Geochemistry of late Archaean stromatolites from Zimbabwe: evidence for microbial life in restricted epicontinental seas. Precambrian Research 132, 379-399.

DOI 10.1016/j.precamres.2004.03.006

Kaufmann, B., Trapp, E. \& Mezger, K. 2004. The Numerical Age of the Upper Frasnian (Upper Devonian) Kellwasser Horizons: A New U-Pb Zircon Date from Steinbruch Schmidt (Kellerwald, Germany). The Journal of Geology 112, 495-501. DOI 10.1086/421077

Kiessling, W., Flügel, E. \& GolonkA, J. 2000. Fluctuations in the carbonate production of Phanerozoic reefs, 191-215. In Insalaco, E., Skelton, P.W \& Palmer, J.T. (eds) Carbonate Platform Systems: Components and Interactions. Geological Society of London, Special Publications 178.

KLAPPER, G. 2007. Conodont taxonomy and the recognition of the Frasnian/Famennian (Upper Devonian) Stage Boundary. Stratigraphy 4(1), 67-76.

Klapper, G., Feist, R., Becker, R.T. \& House, M.R. 1993. Definition of the Frasnian/Famennian Stage boundary. Episodes 16(4), 433-441.

Koptíková, L., Bábek, O., Hladil, J., Kalvoda, J. \& SlavíK, L. 2010. Stratigraphic significance and resolution of spectral reflectance logs in Lower Devonian carbonates of the Barrandian area, Czech Republic; a correlation with magnetic susceptibility and gamma-ray logs. Sedimentary Geology 225, 83-98. DOI 10.1016/j.sedgeo.2010.01.004

KRMíčEK, L. 2006. Petrologický výzkum hádského slepence. 109 pp. Master thesis, Masaryk University, Brno, Czech Republic.

Kumpan, T., Bábek, O., Kalvoda, J., Frýda, J. \& Matys Grygar, T. 2014a. A high-resolution, multiproxy stratigraphic analysis of the Devonian-Carboniferous boundary sections in the Moravian Karst (Czech Republic) and a corre- lation with the Carnic Alps (Austria). Geological Magazine 151, 201-215. DOI 10.1017/S0016756812001057

Kumpan, T., Bábek, O., Kalvoda, J., Matys Grygar, T. \& FRÝDA, J. 2014b. Sea-level and environmental changes around the Devonian-Carboniferous boundary in the Namur-Dinant Basin (S Belgium, NE France): a multi-proxy stratigraphic analysis of carbonate ramp archives and its use in regional and interregional correlations. Sedimentary Geology 311, 43-59. DOI 10.1016/j.sedgeo.2014.06.007

Kumpan, T., Bábek, O., Kalvoda, J., Matys Grygar, T., Frýda, J., Becker, R.T. \& Hartenfels, S. 2015. Petrophysical and geochemical signature of the Hangenberg Events: an integrated stratigraphy of the Devonian-Carboniferous boundary interval in the Northern Rhenish Massif (Avalonia, Germany). Bulletin of Geosciences 90(3), 667-694.

DOI 10.3140/bull.geosci.1547

LAZREQ, N. 1999. Biostratigraphie des conodontes du Givétien au Famennien du Maroc Central. Biofaciès et événement Kellwasser. Courier Forschungsinstitut Senckenberg 214, $1-111$.

LI, Y.X. 2000. Famennian tentaculitids of China. Journal of Paleontology 74(5), 969-975. DOI 10.1017/S0022336000033138

LÜNING, S., AdAmson, K. \& CRAIG, J. 2003. Frasnian organic-rich shales in North Africa: regional distribution and depositional model, 165-184. In Artur, T., Macgregor, D.S. \& CAMERon, N.R. (eds) Petroleum Geology of Africa: New Themes and Developing Technologies. Geological Society of London, Special Publications 207.

Lüning, S., Wendt, J., Belka, Z. \& Kaufmann, B. 2004. Temporal-spatial reconstruction of the early Frasnian (Late Devonian) anoxia in NW Africa; new field data from the Ahnet Basin (Algeria). Sedimentary Geology 163, 237-264.

DOI 10.1016/S0037-0738(03)00210-0

Lyons, T. W. \& Severmann, S. 2006. A critical look at iron paleoredox proxies: New insights from modern euxinic marine basins. Geochimica et Cosmochimica Acta 70, 5698-5722. DOI 10.1016/j.gca.2006.08.021

Marynowski, L., Rakociński, M., Borcuch, E., Kremer, B., SCHUBERT, B.A. \& JAHREN, A.H. 2011. Molecular and petrographic indicators of redox conditions and bacterial communities after the F/F mass extinction (Kowala, Holy Cross Mountains, Poland). Palaeogeography, Palaeoclimatology, Palaeoecology 306, 1-14. DOI 10.1016/j.palaeo.2011.03.018

Marynowski, L., Zatoń, M., Rakociński, M., Filipiak, P., Kurkiewicz, S. \& Pearce, T.J. 2012. Deciphering the upper Famennian Hangenberg Black Shale depositional environments based on multi-proxy record. Palaeogeography, Palaeoclimatology, Palaeoecology 346-347, 66-86. DOI 10.1016/j.palaeo.2012.05.020

Matyja, H. \& NARKIEwicz, M. 1992. Conodont biofacies succession near the Frasnian/Famennian boundary - Some Polish examples. Courier Forschungsinstitut Senckenberg 154, $125-147$.

MaynaRd, J.B. 2005. Manganiferous Sediments, Rocks, and Ores, 289-308. In MACKenzIE, F.T. (ed.) Sediments, Diagenesis, and Sedimentary Rocks, Treatise on Geochemistry 7. Elsevier, Amsterdam.

McGhee, G.R. JR. 1996. The Late Devonian Mass Extinction. The Frasnian-Famennian Crisis. 303 pp. Columbia University 
Press, New York.

DOI 10.7312/columbia/9780231160575.001.0001

McGHEE, G.R. JR. 2013. When the Invasion of Land Failed. The Legacy of the Devonian Extinctions, 317 pp. Columbia University Press, New York.

McLaren, D.J. 1970. Presidential address: time, life and boundaries. Journal of Paleontology 48, 801-815.

Meischner, D. 1971. Clastic sedimentation in the Variscan geosyncline east of the River Rhine, 9-43. In MüLLER, G. (ed.) Sedimentology of Parts of Central Europe. International Sedimentological Congress, Guidebook 8, Heidelberg.

Morford, J.L., Martin, W.R., Francois, R. \& Carney, C.M. 2009. A model for uranium, rhenium, and molybdenum diagenesis in marine sediments based on results from coastal locations. Geochimica et Cosmochimica Acta 73, 2938-2960. DOI 10.1016/j.gca.2009.02.029

Murphy, A.E., Sageman, B.B., Hollander, D.J., Lyons, T.W. \& BRETT, C.E. 2000. Black shale deposition and faunal overturn in the Devonian Appalachian basin: clastic starvation, seasonal water column mixing, and efficient biolimiting nutrient recycling. Paleoceanography 15, 280-291.

DOI 10.1029/1999PA000445

NieBUHR, B. 2005. Geochemistry and time-series analyses of orbitally forced Upper Cretaceous marl-limestone rhythmites (Lehrte West Syncline, northern Germany). Geological Magazine 142, 31-55. DOI 10.1017/S0016756804009999

Nováková, T., Matys Grygar, T., BÁbek, O., FamĚra, M., Minaljevič, M. \& StRnad, L. 2013. Distinguishing regional and local sources of pollution by trace metals and magnetic particles in fluvial sediments of the Morava River, Czech Republic. Journal of Soils and Sediments 13, 460-473. DOI 10.1007/s11368-012-0632-8

OlEmPSKA, E. 2002. The Late Devonian Upper Kellwasser Event and entomozoacean ostracods in the Holy Cross Mountains, Poland. Acta Palaeontologica Polonica 47(2), 247-266.

Over, D.J. 2002. The Frasnian/Famennian boundary in central and eastern United States. Palaeogeography, Palaeoclimatology, Palaeoecology 181, 153-169. DOI 10.1016/S0031-0182(01)00477-1

Over, D.J. \& Schinder, E. 2003. Depositional similarities in selected Late Devonian Kellwasser Horizons: Germany, Morocco, and Eastern United States. Geological Society of America, Abstracts with Programs 35(6), 384.

Plank, T. \& Langmuir, C.H. 1998. The geochemical composition of subducting sediment and its consequences for the crust and mantle. Chemical Geology 145, 325-394. DOI 10.1016/S0009-2541(97)00150-2

Posenato, R., Holmer, L.E. \& Prinoth, H. 2014. Adaptive strategies and environmental significance of lingulid brachiopods across the late Permian extinction. Palaeogeography, Palaeoclimatology, Palaeoecology 399, 373-384.

DOI 10.1016/j.palaeo.2014.01.028

Přichystal, A. 1993. Paleozoic to Quaternary volcanism in the geological history of Moravia and Silesia, 59-70. In Přichystal, A., Obstová, V. \& Suk, M. (eds) Geologie Moravy a Slezska, Faculty of Sciences, Masaryk University.

Pujol, F., Berner, D. \& STÜBEn, D. 2006. Palaeoenvironmental changes at the Frasnian/Famennian boundary in key European sections: Chemostratigraphic constraints. Palaeogeography,
Palaeoclimatology, Palaeoecology 240, 120-145. DOI 10.1016/j.palaeo.2006.03.055

RABIEN, A. 1956. Zur Stratigraphie und Fazies des Oberdevons in der Waldecker Hauptmulde. Abhandlungen des hessischen Landesamtes für Bodenforschung 16, 1-83.

RACHOLD, V. \& BRUMSACK, H.J. 2001. Inorganic geochemistry of Albian sediments from the Lower Saxony basin, NW Germany: paleoenvironmental constraints and orbital cycles. Palaeogeography, Palaeoclimatology, Palaeoecology 174, 123-144. DOI 10.1016/S0031-0182(01)00290-5

RACKI, G. 2005. Towards understanding Late Devonian global events: few answers, many questions, 5-36. In Over, D.J., Morrow, J.R. \& Wignall, P.B. (eds) Understanding Late Devonian and Permian-Triassic Biotic and Climatic Events: Towards an Integrated Approach. Developments in Palaeontology and Stratigraphy Series 20. Elsevier, Amsterdam.

RACKI, G. 2012. The Alvarez impact theory of mass extinction; limits to its applicability and the "great expectations syndrome”. Acta Palaeontologica Polonica 57(4), 681-702. DOI 10.4202/app.2011.0058

Racki, G., Baliński, A., Wrona, R., MaŁKowski, K., Drygant, D. \& Szaniawski, H. 2012. Faunal dynamics across the Silurian-Devonian positive isotope excursions $\left(\delta^{13} \mathrm{C}, \delta^{18} \mathrm{O}\right)$ in Podolia, Ukraine: Comparative analysis of the Ireviken and Klonk events. Acta Palaeontologica Polonica 57(4), 795-832. DOI 10.4202/app.2011.0206

Racki, G., Racka, M., Matyja, H. \& Devleeschouwer, X. 2002. The Frasnian/Famennian boundary interval in the South Polish-Moravian shelf basins: integrated event-stratigraphical approach. Palaeogeography Palaeoclimatology Palaeoecology 181, 251-297. DOI 10.1016/S0031-0182(01)00481-3

RAKociŃSKI, M. \& RACKI, G. 2016. Microbialites in the shallow-water marine environments of the Holy Cross Mountains (Poland) in the aftermath of the Frasnian-Famennian biotic cisis. Global and Planetary Change 136, 30-40.

DOI 10.1016/j.gloplacha.2015.12.001

Rakociński, M., Pisarzowska, A., Janiszewska, K. \& Szrek, P. 2016. Depositional conditions during the Lower Kellwasser Event (Late Frasnian) in the deep-shelf Łysogory Basin of the Holy Cross Mountains Poland. Lethaia 49, 571-590. DOI 10.1111/let.12167.

RiDER, M.H. 1999. The Geological Interpretation of Well Logs. 288 pp. Whittles Publishing Services, Dunbeath.

Riquier, L., Averbuch, O., Devleeschouwer, X. \& TriboVILLARD, N. 2009. Diagenetic versus detrital origin of the magnetic susceptibility variations in some carbonate Frasnian-Famennian boundary sections from Northern Africa and Western Europe: implications for paleoenvironmental reconstructions. International Journal of Earth Sciences 99, 57-73. DOI 10.1007/s00531-009-0492-7

Riquier, L., Tribovillard, N., Averbuch, O., Devleeschouwer, X. \& Riboulleau, A. 2006. The Late Frasnian Kellwasser horizons of the Harz Mountains (Germany): two oxygen-deficient periods resulting from different mechanisms. Chemical Geology 233, 137-155. DOI 10.1016/j.chemgeo.2006.02.021

Riquier, L., Tribovillard, N., Averbuch, O., Joachimski, M.M., Racki, G., Devleeschouwer, X., El Albani, A. \& Riboulleau, A. 2005. Productivity and bottom water redox conditions at the Frasnian-Famennian boundary on both sides 
of the Eovariscan Belt: constraints from trace element geochemistry, 199-224. In Over, D.J., Morrow, J.R. \& Wignall, P.B. (eds) Understanding Late Devonian and Permian-Triassic biotic and climatic events: towards an integrated approach. Developments in Palaeontology and Stratigraphy 20. Elsevier, Amsterdam.

Ruffell, A. \& Worden, R. 2000. Palaeoclimate analysis using spectral gamma-ray data from the Aptian (Cretaceous) of southern England and southern France. Palaeogeography, Palaeoclimatology, Palaeoecology 155, 265-283. DOI 10.1016/S0031-0182(99)00119-4

Sageman, B.B. \& Lyons, T.W. 2005. Geochemistry of fine-grained sediments and sedimentary rocks, 115-158. In MackenZIE, F.T. (ed.) Sediments, Diagenesis, and Sedimentary Rocks, Treatise on Geochemistry 7. Elsevier, Amsterdam.

SANDBerg, C.A., Ziegler, W., Dreesen, R. \& Butler, J.L. 1988. Late Frasnian mass extinction: conodont event stratigraphy, global changes, and possible causes. Courier Forschungsinstitut Senckenberg 102, 263-307.

SCHINDLER, E. 1988. Stop B 12 Aeke valley. Courier Forschungsinstitut Senckenberg 102, 211-213.

Schindler, E. 1990a. The Late Frasnian (Upper Devonian) Kellwasser Crisis. Lecture Notes in Earth Sciences 30, 151-159. DOI 10.1007/BFb0011143

SCHINDLER, E. 1990b. Die Kellwasser-Krise (hohe Frasne-Stufe, Ober-Devon). Göttinger Arbeiten zur Geologie und Paläontologie 46, 1-115.

SCHINDLER, E. 1993. Event-stratigraphical markers within the Kellwasser Crisis near the Frasnian/Famennian boundary (Upper Devonian) in Germany. Palaeogeography, Palaeoclimatology, Palaeoecology 104, 115-125. DOI 10.1016/0031-0182(93)90124-2

SCHINDLER, E. 2012. Tentaculitoids - an enigmatic group of Palaeozoic fossils, 479-490. In TALENT, J.A. (ed.) Earth and Life: Global Biodiversity, Extinction Intervals and Biogeographic Perturbations Through Time. Springer, Dordrecht, Heidelberg, London, New York. DOI 10.1007/978-90-481-3428-1

Schindler, E., Schülke, I. \& Ziegler, W. 1998. The Frasnian/Famennian boundary at the Sessacker Trench section near Oberscheld (Dill Syncline, Rheinisches Schiefergebirge, Germany). Senckenbergiana lethaea, 77(1-2), 243-261.

Schlegel, M.S., Manceau, A., Charlet, L., Chateigner, D. \& HAZEMANN, J.L. 2001. Sorption of metal ions on clay minerals. III. Nucleation and epitaxial growth of Zn phyllosilicate on the edges of hectorite. Geochimica et Cosmochimica Acta 65(22), 4155-4170. DOI 10.1016/S0016-7037(01)00700-1

Schmid, H. 1925. Schwellen- und Beckenfazies im ostrheinischen Paläozoikum. Zeitschrift der Deutschen Geologischen Gesellschaft 77, 226-234.

SchmidT, H. 1935. Die bionomische Einteilung der fossilen Meeresböden. Fortschritte der Geologie und Paläontologie $12,1-154$.

Schnetger, B., Brumsack, H.J., Schale, H., Hinrichs, J. \& DitTert, L. 2000. Geochemical characteristics of deep-sea sediments from the Arabian Sea: a high-resolution study. Deep Sea Research II: Topical Studies in Oceanography 47, 2735-2768. DOI 10.1016/S0967-0645(00)00047-3

SchÜLKe, I. 1995. Evolutive Prozesse bei Palmatolepis in der frühen Famenne-Stufe (Conodonta, Oberdevon). Göttinger Arbeiten zur Geologie und Paläontologie 67, 1-108.

Schulte, P. \& SpeiJer, R.P. 2009. Late Maastrichtian-Early Paleocene sea level and climate changes in the Antioch Church Core (Alabama, Gulf of Mexico margin, USA): A multi-proxy approach. Geologica Acta 7, 11-34.

Sdiri, A.T., Higashi, T. \& Jamoussi, F. 2014. Adsorption of copper and zinc onto natural clay in single and binary systéme. International Journal of Environmental Science and Technology 11, 1081-1092. DOI 10.1007/s13762-013-0305-1

ShEn, J.W., WebB, G.E. 2008. The role of microbes in reef-building communities of the Cannindah limestone (Mississippian), Monto region, Queensland, Australia. Facies 54, 89-105. DOI 10.1007/s10347-007-0116-2

Shen, J.W., Webb, G.E. \& JeLl, J.S. 2008. Platform margins, reef facies, and microbial carbonates; a comparison of Devonian reef complexes in the Canning Basin, Western Australia, and the Guilin region, South China. Earth-Science Reviews 88, 33-59. DOI 10.1016/j.earscirev.2008.01.002

Shen, J.W., WebB, G.E. \& Qing, H. 2010. Microbial mounds prior to the Frasnian-Famennian mass extinctions, Hantang, Guilin, South China. Sedimentology 57, 1615-1639. DOI 10.1111/j.1365-3091.2010.01158.x

Śliwiński, M.G., Whalen, M.T. \& DAY, J. 2010. Trace element variations in the Middle Frasnian punctata Zone (Late Devonian) in the western Canada sedimentary basin - changes in oceanic bioproductivity and paleoredox spurred by a pulse of terrestrial afforestation? Geologica Belgica 13(4), 459-482.

Spalletta, C., Perri, M.C., Over, D.J. \& Corradini, C. 2017. Famennian (Upper Devonian) conodont zonation: revised global standard. Bulletin of Geosciences 92(1), 31-57. DOI 10.3140/bull.geosci.1623

ŠTelcl, J. 1969. Polymiktní slepence z Hádů u Brna. Folia Univerisitatis Purkynianae brunensis, Geologia 19, 3-38.

STReitovÁ, M. 1994. Hranice frasnu a famenu mezi Hády a Šumberovou skálou v jižní části Moravského krasu. Geologické výzkumy na Moravě a ve Slezsku v roce 1993, 65-66.

SzULCZEWSKI, M. 1989. Swiatowe I regionalne zdarzenia w zapisie stratygraficznym pogranicza franu I famenu Gór Swietodrzyskich. Przeglad geologiczny 11, 551-557.

TAYlor, S.R. \& McLennan, S.M. 1985. The Continental Crust: Its Composition and Evolution. 312 pp. Blackwell, Palo Alto.

Tribovillard, N., Algeo, T.J., Lyons, T. \& Riboulleau, A. 2006. Trace metals as paleoredox and paleoproductivity proxies: An update. Chemical Geology 232, 12-32.

DOI 10.1016/j.chemgeo.2006.02.012

Tribovillard, N., Averbuch, O., Devleeschouwer, X., Racki, G. \& Ribolleau, A. 2004. Deep-water anoxia over the Frasnian-Famennian boundary (La Serre, France): a tectonically induced oceanic anoxic event? Terra Nova 16, 288-295. DOI 10.1111/j.1365-3121.2004.00562.x

Tucker, M.E. 1974. Sedimentology of Palaeozoic pelagic limestones: The Devonian Griotte (Southern France) and Cephalopodenkalk (Germany), 71-92. In Hsü, K.J. \& Jenkyns, H.C. (eds) Pelagic Sediments: on Land and under the Sea. Special Publication of the International Association of Sedimentologists 1. Blackwell, Oxford. DOI 10.1002/9781444304855.ch4 
TuCKeR, M.E. \& Wright, V.P. 1990. Carbonate depositional systems II: deeper-water facies of pelagic and resedimented limestones, 228-283. In TuCKER, M.E. \& WRIGHT, V.P. (eds) Carbonate Sedimentology. Blackwell, Oxford.

VAN DERWEIJDEN, C.H. 2002. Pitfalls of normalization of marine geochemical data using a common divisor. Marine Geology 184, 167-187. DOI 10.1016/S0025-3227(01)00297-3

WALliser, O.H. 1984a. Geologic processes and global events. Terra Cognita 4, 17-20.

Walliser, O.H. 1984b. Pleading for a natural D/C-boundary. Courier Forschungsinstitut Senckenberg 67, 241-246.

WALliser, O.H. 1986. The IGCP Project 216 "Global Biological Events in Earth History". Lecture Notes in Earth Sciences 8, 1-4. DOI 10.1007/BFb0010186

WALliser, O.H. 1996. Global events in the Devonian and Carboniferous, 225-250. In WALLISER, O.H. (ed.) Global events and event stratigraphy in the Phanerozoic. Springer, Berlin.

WendT, J. \& BelKa, Z. 1991. Age and depositional environment of Upper Devonian (Early Frasnian to Early Famennian) black shales and limestones (Kellwasser Facies) in the eastern Anti-Atlas, Morocco. Facies 25, 51-90.

DOI 10.1007/BF02536755

Whalen, M.T. \& DAY, J. 2010. Cross-basin variations in magnetic susceptibility infuenced by changing sea level, paleogeography, and paleoclimate: upper Devonian, Western Canada. Journal of Sedimentary Research 80, 1109-1127. DOI 10.2110/jsr.2010.093

Whalen, M.T., Day, J., Eberli, G.P. \& Homewood, P.W. 2002. Microbial carbonates as indicators of environmental change and biotic crises in carbonate systems: examples from the Late Devonian, Alberta Basin, Canada. Palaeogeography, Palaeoclimatology, Palaeoecology 181, 127-151. DOI 10.1016/S0031-0182(01)00476-X

Whalen, M.T., Śliwiński, M.G., Payne, J.H., Day, J.E., Chen, D. \& DA Silva, A.C. 2015. Chemostratigraphy and magnetic susceptibility of the Late Devonian Frasnian-Famennian transition in western Canada and southern China: implications for carbon and nutrient cycling and mass extinction, 37-72. In DA Silva, A.C., Whalen, M.T., Hladil, J., Chadimova, L., Chen, D., Spassov, S., Boulvain, F. \& Devleeschouwer, X. (eds) Magnetic Susceptibility Application: A Window onto Ancient
Environments and Climatic Variations. Geological Society of London, Special Publications 414.

Wignall, P.B. \& Myers, K.J. 1988. Interpreting benthic oxygen levels in mudrocks: a new approach. Geology 16, 452-455. DOI 10.1130/0091-7613(1988)016<0452:IBOLIM>2.3.CO;2

Wood, R. 2000. Palaeoecology of a Late Devonian back reef: Canning Basin, Western Australia. Palaeontology 43(4), 671-703. DOI 10.1111/1475-4983.00145

Wood, R. 2004. Palaeoecology of a post-extinction reef: Famennian (Late Devonian) of the Canning Basin, North-Western Australia. Palaeontology 47(2), 415-445. DOI 10.1111/j.0031-0239.2004.00373.x

Yudina, B.A., Racki, G., Savage, N.M., Racka, M. \& MaŁKowski, K. 2002. The Frasnian-Famennian events, Subpolar Urals: biotic, depositional, and geochemical records. Acta Palaeontologica Polonica 47, 355-372.

Zatoń, M., Zhuravlev, A.V., Rakociński, M., Filipiak, P., Borszcz, T., KrawcZyński, W., Wilson, M.A. \& SoKiran, E.V. 2014. Microconchid-dominated cobbles from the Upper Devonian of Russia: opportunism and dominance in a restricted environment following the Frasnian-Famennian biotic crisis. Palaeogeography, Palaeoclimatology, Palaeoecology 401, 142-153.

DOI 10.1016/j.palaeo.2014.02.029

Zheng, Y., Anderson, R.F., van Geen, A. \& Fleisher, M.Q. 2002. Preservation of nonlithogenic particulate uranium in marine sediments. Geochimica et Cosmochimica Acta 66, 3085-3092. DOI 10.1016/S0016-7037(01)00632-9

ZIEGLER, W. (1962): Taxonomie und Phylogenie oberdevonischer Conodonten und ihre stratigraphische Bedeutung. Abhandlungen des hessischen Landesamtes für Bodenforschung 38, $1-166$.

ZIEGLER, W. (1969): Eine neue Conodontenfauna aus dem höhsten Oberdevon. Fortschritte Geologie von Rheinland und Westfalen 17, 171-191.

Ziegler, W. \& SAndBerg, C.A. 1990. The Late Devonian Conodont Standard Zonation. Courier Forschungsinstitut Senckenberg 121, 1-115.

ZukalovÁ, V. 1980. Stromatoporoids in the Devonian carbonate complex in Moravia (Czechoslovakia). Acta Palaeontologica Polonica 25, 671-679. 